\title{
Transnational Public Law Litigation
}

\author{
Harold Hongju Koh†
}

Several years ago, I called attention to the burgeoning of "transnational public law litigation": suits brought in United States courts by individual and governmental litigants challenging violations of international law. ${ }^{1}$ As recent examples of this phenomenon, I included international human rights suits brought by aliens against foreign and United States governments and officials under the Alien Tort Statute, ${ }^{2}$ as well as actions by foreign governments against individual, American government, and corporate defendants. ${ }^{3}$

Like its domestic counterpart (christened fifteen years ago by Abram Chayes), transnational public law litigation seeks to vindicate public rights and values through judicial remedies. ${ }^{4}$ In both settings, parties bring "public ac-

$\dagger$ Professor, Yale Law School. This article builds upon ideas sketched in Koh, Civil Remedies for Uncivil Wrongs: Combatting Terrorism Through Transnational Public Law Litigation, 22 TEX. INT'L L.J. 169 (1987) and presentations delivered to annual meetings of the American Society of International Law, the American Bar Association Section on International Law and Practice, and the David Berger Program on Complex Litigation at the University of Pennsyivania Law School. I should disclose that I have participated in several of the lawsuits discussed here as a government or private attorney. See Brief of United States as Amicus Curiae urging denial of Certiorari, Tel-Oren v. Libyan Arab Republic, 24 I.L.M. 427 (1985) (co-author); Amicus Curiae Memorandum of International Law Scholars and Practitioners in Trajano v. Marcos, reprinted in 12 HASTINGS INT'L \& COMP. L. REV. 1 (1988) (co-author); Paul v. Avril, No. 91-0399 (S.D. Fla. filed Feb. 28, 1991) (co-counsel for plaintiffs); Xuncax v. Gramajo, No. 91I1564WD (D. Mass. filed June 6, 1991) (co-counsel for plaintiffs). I am grateful to Bruce Ackerman, Akhil Amar, Kay Bradley, Gene Coakley, Henry P. Davis, William S. Dodge, Tom Farer, Mary-Christy Fisher, Owen Fiss, Willy Fletcher, Martin Krajcinovic-Sabelli, Susan M. Mathews, Gerry Neuman, Michael Ratner, Peter Schuck, Ursula Werner, and the George Washington work-in-progress seminar for wonderful insight and support, and to Lea Brilmayer, for enduring friendship and colleagueship.

1. See Koh, supra note $\dagger$, at 193-201. See also H. KOH, THE NATIONAL SECURITY CONSTITUTION: SHARING POWER AFTER THE IRAN-CONTRA AFFAIR $317 \mathrm{n} .27$ (1990); Koh, The Responsibility of the Importer State, in TRANSFERRING HaZardous TECHNOLOGIES AND SubSTANCES: THE INTERNATIONAL LEgaL CHALLENGE 170, 194 (G. Handl \& R. Lutz eds. 1989) [hereinafter Koh, Importer State Responsibility]; Koh, The Palestine Liberation Organization Mission Controversy, 82 AM. SOC'Y INT'L PROC. 534, 546-50 (1988) (all noting the existence of transnational public law litigation).

2. 28 U.S.C. § 1350 (1988). See. e.g., Filartiga v. Peña-Irala, 630 F.2d 876 (2d Cir. 1980); cases cited in infra notes 119 \& $121-22$

3. See, e.g., Republic of Philippines v. Marcos, 862 F.2d 1355 (9th Cir. 1988) (en banc), cert. denied, 490 U.S. 1035 (1989); In re Union Carbide Corp. Gas Plant Disaster at Bhopal, India in December, 1984, 809 F.2d 195 (2d Cir. 1987); Republic of Philippines v. Marcos, 806 F.2d 344 (2d Cir. 1986), cert. dismissed sub nom. Ancor Holdings, N.V. v. Republic of Philippines, 480 U.S. 942 (1987). See generally Koh, Importer State Responsibility, supra note 1, at 191-96; text accompanying infra notes 125-29.

4. Compare infra text accompanying note 130 (defining distinctive traits of transnational public law litigation) with Chayes, The Role of the Judge in Public Law Litigation, 89 HARV. L. REV. 1281 (1976) [hereinafter Chayes, Public Law Litigation]; Chayes, The Supreme Court, 198I Term-Foreword: Public Law Litigation and the Burger Court, 96 HARV. L. REV. 4 (1982). Not coincidentally, Professor Chayes was also the architect of a prominent recent example of transnational public law litigation, Nicaragua's suit 
tions," asking courts to declare and explicate public norms, often with the goal of provoking institutional reform. ${ }^{5}$ Much as domestic public law litigants have pursued Bivens and Section 1983 litigation in federal courts seeking redress, deterrence, and reform of state and federal institutions through judicial enunciation of constitutional norms, transnational public law litigants have sought redress, deterrence, and reform of national governmental policies through clarification of rules of international conduct. ${ }^{6}$

What makes transnational public law litigation unique, however, is its melding of two conventional modes of litigation that have traditionally been considered distinct. In traditional domestic litigation, private individuals bring private claims against one another based on national law before competent domestic judicial fora, seeking both enunciation of norms and damages relief in the form of a retrospective judgment. ${ }^{7}$ In traditional international litigation, nation-states bring public claims against one another based on treaty or customary international law before international tribunals of limited competence. Although state litigants ostensibly seek judgments from such tribunals, their primary goal is usually the enunciation of a public international norm that will stimulate "relief" in the form of a negotiated political settlement. ${ }^{8}$

Transnational public law litigation merges these two classical modes of litigation. Private individuals, government officials, and nations sue one another directly, and are sued directly, in a variety of judicial fora, most prominently, domestic courts. In these fora, these actors invoke claims of right based not solely on domestic or international law, but rather, on a body of "transnational"

against the United States in the International Court of Justice. See Chayes, Nicaragua, the United States and the World Court, 85 COLUM. L. REV. 1445 (1985) [hereinafter Chayes, Nicaragua].

5. See P. BATOR, D. MELTZER, P. MISHKIN \& D. ShapiRo, HART AND WEChSLER's THE Federal COURTS AND THE FEDERAL SYSTEM 79-80 (3d ed. 1988) (defining "public action" model of judiciary's role).

6. Bivens v. Six Unknown Named Agents of the Federal Bureau of Narcotics, 403 U.S. 388 (1971); 42 U.S.C. $\$ 1983$ (1988). Compare Eisenberg \& Yeazell, The Ordinary and the Extraordinary in Institutional Litigation, 93 HARV. L. REV. 465 (1980) with Chayes, Nicaragua, supra note 4, at 1479-80 (comparing the World Court's Nicaragua decision with Brown v. Board of Educ., 347 U.S. 483 (1954)).

7. For the classic description of this "private law" paradigm of domestic adjudication, see Fuller, The Forms and Limits of Adjudication, 92 HARV. L. REV. 353 (1978). But cf. Chayes, Public Law Litigation, supra note 4 (presenting counter-model of domestic public law litigation); Fiss, The Social and Political Foundations of Adjudication, 6 LAW \& HUM. BEHAV. 121 (1982) (contrasting private and public models of domestic adjudication).

8. The archetype of this form of international adjudication is litigation before the International Court of Justice (ICJ) seeking an advisory opinion pursuant to Article 96 of the United Nations Charter. U.N. CHARTER art. 96. Such an opinion does not purport to be a binding judgment; rather, it enunciates public international norms in a way that gives some litigants a greater claim of right in subsequent settlement negotiations. See Military and Paramilitary Activities (Nicar. v. U.S.), 1986 I.C.J. 14, 172 (June 27) (separate opinion of Judge Lachs) (the World Court's "real function, whatever the character of the dispute, is "to facilitate, so far as is compatible with its Statute, a direct and friendly settlement."') (citation omitted), reprinted in 25 I.L.M. 1023, 1102 (1986); Ago, "Binding" Advisory Opinions of the International Court of Justice, 85 AM. J. INT'L L. 439 (1991) (noting increasing use of ICJ advisory opinions to settle disputes). See generally Bilder, International Dispute Settlement and the Role of International Adjudication, 1 EMORY J. INT'L DISPUTE RESOL. 131, 133-38 (1987) (describing characteristics of international adjudication). 
law that blends the two. ${ }^{9}$ Moreover, contrary to "dualist" views of international jurisprudence, which see international law as binding only upon nations in their relations with one another, ${ }^{10}$ individual plaintiffs engaged in this mode of litigation usually claim rights arising directly from this body of transnational law.

As in traditional domestic litigation, transnational public lawsuits focus retrospectively upon achieving compensation and redress for individual victims. But as in traditional international law litigation, the transnational public law plaintiff pursues a prospective aim as well: to provoke judicial articulation of a norm of transnational law, with an eye toward using that declaration to promote a political settlement in which both governmental and nongovernmental entities will participate. Thus, although transnational public law plaintiffs routinely request retrospective damages or even prospective injunctive relief, their broader strategic goals are often served by a declaratory or default judgment announcing that a transnational norm has been violated. Even a judgment that the plaintiff cannot enforce against the defendant in the rendering forum empowers the plaintiff by creating a bargaining chip for use in other political fora. ${ }^{11}$

With characteristic cogency, Lea Brilmayer shouts two cheers for transnational public law litigation. ${ }^{12}$ She correctly perceives that transnational litiga-

9. In his Storrs Lectures, Judge Philip Jessup rejected the term "international law" in favor of "transnational law," defined as "all law which regulates actions or events that transcend national frontiers" and including "[b]oth public and private international law ... Iplus] other rules which do not wholly fit into such standard categories." P. JESSUP, TRANSNATIONAL LAW 2 (1956). The American Law Institute's RESTATEMENT (THIRD) OF THE FOREIGN RELATIONS LAW OF THE UNTED STATES (1987) [hereinafter RESTATEMENT (THIRD)] constitutes perhaps the most complete compendium of this hybrid body of private and public, domestic and international law. See also H. STEINER \& D. VAGTS, TRANSNATIONAL LEGAL PROBLEMS (3d ed. 1986).

10. International law scholars distinguish between "monism"- the school of international jurisprudence that views international and domestic law as together constituting a unified legal system-and "dualism," the school that "view[s] international law as a discrete legal system" that "is for nations" only and "operates wholly on an inter-nation plane." Henkin, The Constitution and United States Sovereignty: A Century of Chinese Exclusion and lis Progeny, 100 HARv. L. REv. 853, 864 (1987); see also Starke, Monism and Dualism in the Theary of International Law, 1936 BRIT. Y.B. INT'L L. 66. A strictly dualistic view denies a meaningful role to both individuals and domestic courts in the making of international law. In a dualistic system, individuals injured by foreign states would have no right to pursue claims directly against those states in either domestic or international fora. Instead, their states would pursue those claims for them on a discretionary basis in international fora, and subsequently determine the rights of those injured individuals to redress as a matter of domestic law.

11. Of course, all tort judgments, whether domestic or transnational, serve several ends: compensation of the victims; denial of safe haven to the defendant in the judgment-rendering forum; deterrence of others who might contemplate similar conduct: and enunciation of legal norms opposing the conduct for which the defendant has been found liable. Although uncollected judgments leave victims uncompensated, they nevertheless serve the other three objectives. To emphasize that transnational public law plaintiffs seek judicial articulation of legal norms is not to deny either their interest in or their entitlement to compensation. The point is simply that norm-enunciation, deterrence, and denial of safe haven assume greater prominence in a transnational setting, where highly mobile defendants and the absence of full faith and credit impair the collectability of judgments. (1991).

12. Brilmayer, Imernational Law in American Courts: A Modest Proposal, 100 YALE L.J. 2277, 2313 
tion in domestic courts eschews both the traditional party structure and the normative sources of classical international law litigation. She further argues-correctly, in my view-that international law claims do not differ so markedly from domestic law claims as to render them inherently unfit for domestic judicial resolution. Her "modest proposal" would justify judicial resolution of such transnational cases based upon her "vertical model" of international adjudication. That model holds that only "vertical" cases-i.e., those predominantly raising issues pitting the rights of individuals against the power of the state-properly belong in American courts. ${ }^{13}$ But inherent in Brilmayer's thesis is a controversial limiting principle: that American courts may legitimately exclude from their dockets cases that do not meet her vertical criteria. For a United States court to decide an international law issue, she argues, "the case or controversy must touch on the international law rights of individuals and not merely on the ["horizontal"] rights of co-equal sovereign states." 14

While I applaud Professor Brilmayer's efforts to bring order to this field, I fear that she overlooks history and claims too much for her vertical approach in search of a simple rule that would solve all international adjudications in domestic courts. In so doing, she gives short shrift to the complex balance of public values-particularly concerns about comity, separation of powers, and judicial competence- that different types of transnational public law cases raise. More troubling, upon inspection, her limiting principle-like most modest proposals since Swift's ${ }^{15}$ - proves not to be so modest after all. Mechanically applied, it would offer United States judges a tempting rationale for excluding from their dockets important transnational public law cases and issues that courts are both competent and constitutionally obliged to adjudicate.

The first part of this article supplies important historical and international background that is largely omitted from Brilmayer's analysis. Part II critiques her "modest" proposal and offers what I consider a superior approach to deciding international law cases in American courts. The third and final part explains why this doctrinal debate is important to a larger understanding of the newly emerging international legal process.

\section{The Evolution of Transnational Public LaW Litigation}

Based upon a current snapshot of international law cases in United States courts, Professor Brilmayer implies that the domestic litigation of international

13. See Brilmayer, supra note 12 , at $2296 \mathrm{n} .103$. This model of adjudication apparently grows out of L. BRILMAYER, JUSTIFYING INTERNATIONAL ACTS (1989), which argues more broadly for application of a "vertical thesis" of international relations.

14. Brilmayer, supra note 12 , at 2280 .

15. Cf. J. SWIFT, A MODEST PROPOSAL For PREVENTING THE CHILdREN OF POOR PEOPLE IN IRELAND FROM BEING A BURdEN TO THEIR PARENTS OR COUNTRY: AND FOR MAKING THEM BENEFICIAL TO THE PUBLIC (C. Beaumont ed. 1969) ("proposing" cannibalism of Irish infants as solution to poverty problem). 
law claims is somehow a new, rather than a resurgent, phenomenon. ${ }^{16}$ She further suggests that international law has only recently begun to address "not just . . . 'horizontal' relations between states, but also ... 'vertical' relations between states and people."17 Yet even a cursory review of well-trodden history makes clear that transnational public law litigation has a long and distinguished lineage in American courts.

\section{A. The Law of Nations in American Courts}

Centuries before Jeremy Bentham coined the "horizontal" term "international law" in $1789,{ }^{18}$ jurists recognized the existence of a "vertical" "law of nations," which bound individuals no less than states. As early as the second century, the Romans spoke of a jus gentium "common to all men." ${ }^{19}$ Sixteenth and seventeenth century legal scholars, such as Grotius, did not distinguish municipal from international law, instead viewing the law of nations as a universal law binding upon all mankind. ${ }^{20}$ Blackstone described the law of nations as "a system of rules, deducible by natural reason, and established by universal consent among the civilized inhabitants of the world ... to insure the observance of justice and good faith, in that intercourse which must frequently occur between two or more independent states, and the individuals belonging to each."21 Thus, the law of nations embraced private as well as public, domestic as well as international transactions. It encompassed not simply the law governing "horizontal" relations among states (the so-called "law of states")-for example, rules relating to passports and ambassadors-but also the "law maritime" (affecting prizes, shipwrecks, admiralty, and the like) and the "law merchant" (lex mercatoria) applicable to transnational commercial transactions. 22

As England became the preeminent global power, the law of nations was domesticated first into English common law, then applied to the American

16. Brilmayer notes in passing, but never elaborates upon, the important role of the law of nations before early American courts. See Brilmayer, supra note 12, text accompanying note 82.

17. Id. at 2295.

18. J. BENTHAM, AN INTRODUCtion to the PRINCIPLES OF MORALS AND LEGISLATION 296-97 (J. Burns \& H. Hart eds. 1970).

19. See M. JANIS, AN INTROduction to InTERNATIONAL LAW 1, n.2 (1988) (citing The Four Commentaries of Gaius on the Institutes of the Civil Law, 1 THE CIVIL LAW 81 (S. Scott ed. 1973)).

20. See Kennedy, Primitive Legal Scholarship, 27 HARv. INT'L L.J. I, 8 (1986) (discussing works of Vitoria, Suarez, Gentili and Grotius): Dickinson, The Law of Nations as Part of the National Law of the United States (pt. 1), 101 U. PA. L. REV. 26, 26-27 (1952).

21. 4 W. BLACKSTONE, COMMENTARIES *66 (emphasis added).

22. Dickinson, supra note 20, at 27: Berman \& Kaufman, The Law of International Commercial Transactions (Lex Mercatoria), 19 HARV. INT'L L.J. 221, 224-29 (1978) (law merchant was transnational private law based not on any single national law but on mercantile customs generally accepted by trading nations). 
colonies, and subsequently incorporated into United States law. ${ }^{23}$ With American independence, the law of nations became part of the common law of the United States. ${ }^{24}$ The Continental Congress resolved to send a diplomatic letter stating that the United States would cause "the law of nations to be most strictly observed." 25 The Federalist Papers made extensive mention of the law of nations' role in United States courts. ${ }^{26}$ In Article I of the Constitution, the Framers expressly gave Congress the power to define and punish "Piracies . . . committed on the high Seas, and Offences against the Law of Nations."27 Moreover, Article III extended the judicial power of the United States not simply to cases arising under the Constitution and laws of the United States, but also to cases arising under treaties, and a large class of international cases-those affecting Ambassadors, public Ministers and consuls, admiralty and maritime cases, and cases involving foreign parties. ${ }^{28}$

The Framers never expected such cases and controversies to be decided solely under domestic law. As Professor White has recounted, "[t]he Framers' Constitution anticipated that international disputes would regularly come before the United States courts, and that the decisions in those cases could rest on principles of international law, without any necessary reference to the common law or to constitutional doctrines." 29 All three branches quickly recognized the applicability of the law of nations in American courts. Executive officials such as Thomas Jefferson heralded the law of nations as "an integral part . . .

23. For discussion of international law in English common law, see Triquet y. Bath, 97 Eng. Rep. 936 (K.B. 1764) (Mansfield, J.). For accounts of how international law became United States law, see Sprout, Theories as to the Applicability of International Law in the Federal Courts of the United States, 26 AM. J. INT'L L. 280 (1932); Henkin, International Law as Law in the United States, 82 MiCH. L. REV. 1555 (1984).

24. In John Jay's words, "the United States had, by taking a place among the nations of the earth, become amenable to the law of nations." Chisholm v. Georgia, 2 U.S. (2 Dall.) 419, 474 (1793). See also Ware v. Hylton, 3 U.S. (3 Dall.) 199, 281 (1796) ("When the United States declared their independence, they were bound to receive the law of nations, in its modern state of purity and refinement."). See generally Jay, The Status of the Law of Nations in Early American Law, 42 VAND. L. REv. 819, 824-28 (1989).

25. 14 JOURNALS OF THE CONTINENTAL CONGRESS 635 (W. Ford ed. 1909).

26. See, e.g., THE FEDERALIST No. 3, at 14, 15, 16 (J. Jay); No. 42, at 271-73 (J. Madison); No. 53, at 351 (J. Madison); No. 80, at 517 (A. Hamilton); No. 83, at 548-49 (A. Hamilton) (Modern Library ed. 1937).

27. U.S. CONST. art. I, $\$ 8$, cl. 10 .

28. U.S. CONST. art. III.

29. White, The Marshall Court and Imernational Law: The Piracy Cases, 83 AM. J. INT'L L. 727, 727 (1989); see also Henkin, stipra note 10, at 868 ("[E]arly United States courts and legislators regarded customary international law and treaty obligations as part of the domestic legal system. International law was domestic law.") (emphasis in original); RESTATEMENT (THIRD), supra note 9. \$111, at 41 (Introductory Note) ("From the beginning, the law of nations, later referred to as international law, was considered to be incorporated into the law of the United States without the need for any action by Congress or the President, and the courts, State and federal, have applied it and given it effect as the courts of England had done."); Tucker, Appendix to 1 W. BLACKSTONE, COMMENTARIES, note E, at 430 (S. Tucker ed. \& comm. 1803) ("the matters cognizable in the federal courts, belong ... partly to the law of nations, partly to the common law of England: ... Is]o that each of these laws may be regarded, so far as they apply to such cases, respectively, as the law of the land"). 
of the laws of the land." ${ }^{30}$ Congress immediately enacted as part of the First Judiciary Act the Alien Tort Statute, which gave the district courts jurisdiction "of all causes where an alien sues for a tort only in violation of the law of nations or a treaty of the United States." ${ }^{31}$ Shortly thereafter, Congress passed statutes criminalizing piracy and assaults upon ambassadors. ${ }^{32}$ American courts regularly decided cases under the law of nations, particularly those involving piracies and prize jurisdiction (captures of enemy ships as prizes of war), and applied and clarified international law principles in cases concerning offenses against the law of nations, acquisition and control of territory, boundary disputes, questions of nationality, foreign sovereign immunity, and principles of war and neutrality. ${ }^{33}$ In short, long before the modern period, United States courts routinely applied international law in domestic cases without regard to whether the dispute concerned private or public international law or could be characterized as "horizontal" or "vertical." 34

Professor Brilmayer treats dualism - the belief that international and domestic law constitute rigidly separate systems-as the traditional and "dominant paradigm" of international law. ${ }^{35}$ But it was not until the mid- to late nineteenth century that dualism began to take hold in the United States. ${ }^{36}$ Gradually, components of the law of nations-the laws maritime and merchant, for example-were domesticated into America's "general common law." Federal courts sitting in admiralty jurisdiction began to apply to domestic watercourses a general maritime law derived from international law, which was deemed subject to congressional modification. ${ }^{37}$ The law merchant took a more sinuous

30. See Letter from Thomas Jefferson, Secretary of State, to M. Genet, French Minister (June 5, 1793), quoted in 1 J. MOORE, DIGEST OF INTERNATIONAL LAW 10 (1906); see also 1 Op. Atty. Gen. 9 (1792) (opinion of Attorney General Randolph) ("The law of nations, though not specially adopted by the constitution, or any municipal act, is essentially a part of the law of the land."); id. at 40 (1797) (opinion of Attorney General Lee).

31. See Judiciary Act of Sept. 24,1789 , ch. $20, \S 9$ (b), 1 Stat. 73,77 (codified as amended at 28 U.S.C. $\S 1350$ (1988)). For legislative history of the Alien Tort Statute, see Burley, The Alien Tort Statute and the Judiciary Act of 1789: A Badge of Honor, 83 AM. J. INT'L L. 461 (1989).

32. See Act of Apr. 30, 1790, ch. 9, \& \&, 1 Stat. 112, 113-14 (discussed in White, supra note 29, at 730-34); Act of Apr. 30, 1790, ch. 9, $\$ 28,1$ Stat. 112, 118.

33. Sec, e.g., U.S. v. Smith, 18 U.S. (5 Wheat.) 153, 155 (1820) (piracy); Thirty Hogsheads of Sugar v. Boyle, 13 U.S. (9 Cranch) 191, 198 (1815) (prize jurisdiction); Respublica v. DeLongchamps, 1 U.S. (1 Dall.) 111, 116 (O. \& T. Pa. 1784) (attacks upon ambassador); United States v. Percheman, 32 U.S. (7 Pet.) 51, 86-87 (1833) (acquisition and control of territory); Iowa v. Illinois, 147 U.S. 1, 8-11 (1893) (boundary disputes); Shanks v. DuPont, 28 U.S. (3 Pet.) 242, 248 (1829) (question of nationality); The Schooner Exchange v. M'Faddon, 11 U.S. (7 Cranch) 116, 125 (1812) (foreign sovereign immunity); The Peterhoff, 72 U.S. (5 Wall.) 28, 54-56 (1867) (principles of war and neutrality).

34. Indeed, nineteenth-century legal scholars did not even treat public and private law as separate categories. See Paul, The Isolation of Private International Law, 7 WIS. INT'L L.J. 149, 155-164 (1988).

35. Brilmayer, supra note 12 , at 2292 ; see also supra notes 10 \& 16.

36. Two leading "dualistic" international law scholars, Triepel and Anzilotti, wrote their major works in the late nineteenth and early twentieth centuries. See Starke, supra note 10, at 70; Janis, Individuals as Subjects of International Law, 17 CORNELL INT'L L.J. 61, 63 n.14 (1984) (citing other late nineteenth and early twentieth century legal scholars expressing this view).

37. See generally Note, From Judicial Grant to Legislative Power: The Admiralty Clause in the Nineteenth Century, 67 HARV. L. REV. 1214, 1230-31 (1954); see also The Rapid, 12 U.S. (8 Cranch) 155, 162 (1814) ("The law of prize is part of the law of nations .... [I]t was the law of England before the 
path, mutating through the centuries from customary international law to English common law to general American common law to state common and statutory law and, within the last decade, returning to positive international law (with the United States' ratification of the United Nations Convention on Contracts for the International Sale of Goods). ${ }^{38}$ But throughout the early nineteenth century, American courts regularly construed and applied the unwritten law of nations as part of the "general common law," particularly to resolve commercial disputes, without regard to whether it should be characterized as federal or state. ${ }^{39}$ In 1842, Justice Story's classic decision in Swift v. Tyson mandated application of the law merchant as general common law in federal diversity cases, announcing: "[ $\mathrm{t}]$ he law respecting negotiable instruments may be truly declared ... to be in a great measure, not the law of a single country only, but of the commercial world." $" 40$

Equally important, nineteenth-century American courts routinely applied the law of nations to decide precisely the kind of public, state-to-state issues that Professor Brilmayer would now deem "horizontal," and hence unfit for adjudication. In the Prize Cases, for example, the Court found that the Civil War constituted a "war" for purposes of international law, whose existence permitted the Union to avail itself of the sovereign rights of a belligerent. ${ }^{41}$ In The Peterhoff, the Court denied the right of the United States to extend its blockade of Texas to neutral Mexican territory, stating: "[I]n cases such as [this], we administer the public law of nations, and are not at liberty to inquire what is for the particular advantage or disadvantage of our own or another country. We must follow the lights of reason and the lessons of the masters of international jurisprudence." 42 Similarly, as American territory expanded, "the Supreme Court from the beginning ... resolved interstate boundary disputes in recourse

revolution, and therefore constitutes a part of the admiralty and maritime jurisdiction conferred on this Court in pursuance of the Constitution.").

38. United Nations Convention on Contracts for the International Sale of Goods, Doc. A/Conf. 97/18, Annex I (Vienna 1980), entered into force Jan. 1, 1988 ("UNCISG"). As England became the leading global commercial power in the eighteenth century, the Iaw merchant was domesticated into English common law, which in turn became part of the American general common law. See Swift v. Tyson, 41 U.S. (16 Pet.) 1 (1842). In 1940, the National Conference of Commissioners on Uniform State laws proposed the idea of the Uniform Commercial Code (UCC), which was also based on existing mercantile custom. The UCC was adopted in 1952, was comprehensively revised in 1956, and is now the law in all states but Louisiana. The UNCISG has been signed by more than twenty nations, including the United States, and entered into force for the United States on January 1, 1988. Thus, by operation of the Supremacy Clause, U.S. CONST. art. VI, the UNCISG now overrides the UCC with respect to contracts for the sale of goods between parties whose places of business are in different countries, if those countries are contracting states.

39. See generally Fletcher, The General Common Law and Section 34 of the Judiciary Act of 1789: The Example of Marine Insurance, 97 HARV. L. REV. 1513, 1515-17 (1984).

40. 41 U.S. (16 Pet.) 1, 19 (1842). Swift held that a federal court sitting in diversity jurisdiction must apply general common law to determine whether a pre-existing debt constitutes sufficient consideration for the endorsement of a bill of exchange so that the endorsee would be treated as a holder in due course.

41. 67 U.S. (2 Black) 635 (1863).

42. 72 U.S. (5 Wall.) 28, 57 (1867); see also The Scotia, 81 U.S. (14 Wall.) 170, 187 (1871) (collision of two ships on high seas) ("Undoubtedly, no single nation can change the law of the sea. That law is of universal obligation ...."). 
to the Law of Nations,"43 and invoked "the law of nations, recognized by all civilized States" to sustain legislation authorizing acquisition of new territory by discovery, possession, and occupation. ${ }^{44}$ To be sure, the courts regularly passed upon the kind of "vertical" expropriation and human rights cases discussed by Professor Brilmayer. ${ }^{45}$ But they did not distinguish, much less hesitate to decide, cases involving such arguably "horizontal" issues as treaty interpretation, the effect of recognition, or a state's right to exclude another state's citizens. ${ }^{46}$

Thus, in 1895, Justice Gray could proclaim in Hilton v. Guyot ${ }^{47}$ that:

International law, in its widest and most comprehensive sense-including not only questions of right between nations, governed by what has been appropriately called the law of nations; but also questions arising under what is usually called private international law, or the conflict of laws, and concerning the rights of persons within the territory and dominion of one nation, by reason of acts, private or public, done within the dominions of another nation-is part of our law, and must be ascertained and administered by the courts of justice, as often as such questions are presented in litigation between man and man, duly submitted to their determination. ${ }^{48}$

Although conceding that treaties or statutes provided American courts with "[t]he most certain guide ... for the decision of such questions," when "there is no written law upon the subject," Justice Gray repeated, "the duty still rests upon the judicial tribunals of ascertaining and declaring what the law is, whenever it becomes necessary to do so, in order to determine the rights of parties to suits regularly brought before them." ${ }^{.49}$

Gray's language makes clear that the primary legacy of Marbury v. Madison to international law cases was not, as Professor Brilmayer has suggested, any limitations imposed by the "case or controversy" requirement, but rather, Marbury's command that "[i]t is emphatically the province and duty of the

43. Dickinson, The Law of Nations as Part of the National Law of the United States (pt. 2), $101 \mathrm{U}$. PA. L. REV. 792, 821 (1953).

44. Jones v. U.S., 137 U.S. 202, 212 (1890); see also Kansas v. Colorado, 206 U.S. 46, 97 (1907) ("'Sitting, as it were, as an international, as well as a domestic tribunal, we apply Federal law, state law, and international law, as the exigencies of the particular case may demand." (quoting The Paquete Habana, 175 U.S. 677, $700(1900))$ ).

45. See, e.g., United States v. Percheman, 32 U.S. (7 Pet.) 51, $86-87$ (1833) (protecting vested rights in private property against successor sovereign); United States v. The Schooner La Jeune Eugenie, $26 \mathrm{~F}$. Cas. 833, 846 (1822) (finding slave trade an offense against the universal law of society).

46. See, e.g., Ware v. Hylton, 3 U.S. (3 Dall.) 199 (1796) (treaty interpretation); Oetjen v. Central Leather Co., 246 U.S. 297, 302-03 (1918) ("It is also the result of the interpretation by this court of the principles of international law that when a government which originates in revolution or revolt is recognized by the political department of our government ... such recognition is retroactive in effect ...."); Chinese Exclusion Case, 130 U.S. 581 (1889) (right to exclude foreigners).

47. 159 U.S. 113 (1895).

48. Id. at 163 (emphasis added).

49. Id. 
judicial department to say what the law is." 50 Nothing in Marbury had limited this law-declaring function to cases involving domestic law. To the contrary, within a year after writing Marbury, Chief Justice John Marshall ruled that "an act of Congress ought never to be construed to violate the law of nations if any other possible construction remains."51 Eleven years later, Marshall further clarified the relationship between statutes and the law of nations, holding that absent a contrary statute, "the Court is bound by the law of nations which is a part of the law of the land." 52 That same year he announced that "[t]he law of nations is the great source from which we derive those rules, respecting belligerent and neutral rights, which are recognized by all civilized and commercial states."53

As the twentieth century opened, Justice Gray repeated almost verbatim his words from Hilton in a famous prize case, The Paquete Habana. ${ }^{54}$ But over the first half of this century, the scope of the law of nations applied in American courts substantially narrowed. By overruling Swift in 1938, Erie R.R. Co. $v$. Tompkins ${ }^{55}$ interred the general common law, raising fears that the law of nations might be subordinated into state, not federal, law. ${ }^{56}$ The laws merchant and maritime were assimilated into domestic law and the public/private distinction seized prominence, as conflict of laws was "privatized" and treated as a body of primarily domestic legal principles governing disputes with foreign interests or persons. ${ }^{57}$ As the century proceeded, the courts increasingly invoked three concerns to mitigate their duty to declare the law of nations: comity, separation of powers, and judicial incompetence. Judicial emphasis upon these three factors - not some artificially clean line between horizontal and vertical cases - explains the courts' recent reluctance to decide international law cases.

50. 5 U.S. (1 Cranch) 137, 177 (1803). For a critique of Brilmayer's reading of Marbury, see infra text accompanying notes 251-265.

51. Murray v. Schooner Charming Betsy, 6 U.S. (2 Cranch) 64, 118 (1804). For a detailed analysis of this principle, see Steinhardt, The Role of International Law As a Canon of Domestic Statutory Construction, 43 VAND. L. REV. 1103 (1990). For a modern application, see United States $v$. Palestine Liberation Organization, 695 F. Supp. 1456 (S.D.N.Y. 1988), discussed infra text accompanying notes 144 \& 146.

52. The Nereide, 13 U.S. (9 Cranch) 388,423 (1815).

53. Thirty Hogsheads of Sugar v. Boyle, 13 U.S. (9 Cranch) 191, 198 (1815).

54. 175 U.S. 677,700 (1900) ("International law is part of our law, and must be ascertained and administered by the courts of justice of appropriate jurisdiction as often as questions of right depending upon it are duly presented for their determination."). In that famous case, the American Navy seized and condemned private Spanish fishing vessels as prizes during the Spanish-American War. The Court ordered compensation for the original owners, finding that under international law private fishing vessels were not subject to seizure as prize. See generally Stucky, The Paquete Habana: A Case History in the Development of International Law, 15 U. BALT. L. REV. I (1985).

55. 304 U.S. 64 (1938) (Constitution and the rules-of-decision clause in Federal Judiciary Act of 1789 require federal courts sitting in diversity jurisdiction to apply state judicial decisions as well as state constitutional and statutory law).

56. See, e.g., Jessup, The Doctrine of Erie Railroad v. Tompkins Applied to International Law, 33 AM. J. INT'L L. 740 (1939); Henkin, supra note 23, at 1558.

57. See generally Paul, supra note 34; Morgan, Internalization of Customary International Law: An Historical Perspective, 12 YALE J. INT'L L. 63 (1987). 
The first factor, comity, gained prominence in Hilton $v$. Guyot. In virtually the same breath as he affirmed the duty of American courts to decide cases based on international law, Justice Gray defined comity as "neither a matter of absolute obligation, on the one hand, nor of mere courtesy and good will upon the other," but "the recognition which one nation allows within its territory to the legislative, executive or judicial acts of another nation, having due regard both to international duty and convenience, and to the rights of its own citizens or of other persons who are under the protection of its laws." 58 Over time, American courts came to read the comity doctrine, derived from European choice-of-law rules and celebrated by Justice Story's famous Commentaries on the Conflict of Laws, to require them to refrain from independent determination of cases under the law of nations. ${ }^{59}$ Instead, the courts would defer to, and at times recognize and enforce, the decisions of foreign sovereigns and courts. The Court gave comity special operational force when it embraced the Act of State doctrine, the principle that "the courts of one country will not sit in judgment on the acts of the government of another done within its own territory." ${ }^{60}$

By emphasizing comity, the Court sought to accommodate respect for foreign sovereignty with growing American intercourse with other nations. Separation of powers and judicial incompetence, the second and third leitmotifs of the Court's new international jurisprudence, surfaced as the Court began increasingly to defer to claimed presidential authority and expertise in foreign affairs. In a series of famous decisions rendered in the 1930's and 40's, the Court upheld and thereby solidified executive branch authority to bind the states and private parties with its foreign policy decisions. ${ }^{61}$ Significantly, however, the Court itself soon came to read these affirmations of vertical executive power in foreign affairs as possessing horizontal force, requiring not just the states and private parties, but the courts and Congress as well, to defer to executive determinations to preserve "one voice" in external affairs. ${ }^{62}$ Moreover, the Court gradually transformed the separation-of-powers requisite that

58. 159 U.S. $113,163-64$ (1895).

59. See generally Paul, Comity In International Law, 32 HARv. INT'L L.J. I (1991); Maier, Extraterritorial Jurisdiction at a Crossroads: An Intersection Between Public and Private International Law, 76 AM. J. INT'L L. 280, 281.85 (1982).

60. Underhill v. Hernandez, 168 U.S. 250, 252 (1897) (noting that "Ie]very sovereign State is bound to respect the independence of every other sovereign State"); Oetjen v. Central Leather Co., 246 U.S. 297, 303-04 (1918) (Act of State doctrine "rests at last upon the highest considerations of international comity and expediency"); Ricaud v. American Metal Co., 246 U.S. 304 (1918).

61. See, e.g., United States v. Curtiss-Wright Export Corp., 299 U.S. 304 (1936); United States v. Pink, 315 U.S. 203 (1942); United States v. Belmont, 301 U.S. 324 (1937); Chicago \& S. Air Lines, Inc. v. Waterman Steamship Co., 333 U.S. 103 (1948). See generally H. KOH, supra note 1, at 93-98 (discussing these cases). The close relationship between these cases and those involving judicial application of international law makes it unwise to treat "foreign policy" as a separate category. But cf. Brilmayer, supra note 12 , at 2277 n.l.

62. See generally Steinhardt, Human Rights Litigation and the "One Voice" Orthodoxy in Foreign Affairs, in WORLD JUSTICE? U.S. COURTS AND INTERNATIONAL HUMAN RIGHTS 23 (M. Gibney ed. 1991). 
the courts defer to executive determinations about international politics into a more extreme institutional conclusion: that courts are somehow incompetent not simply to find facts in international cases, but also to make the very determinations regarding international and foreign affairs law that they had been making since the Republic began. ${ }^{63}$ To the extent that this "judicial incompetence" rationale rested upon the courts' perceived unfamiliarity and inexperience with international cases, it would shortly become a self-fulfilling prophecy.

\section{B. Modern Transnational Public Law Litigation}

Modern transnational public law litigation began with the 1946 war crimes trials at Nuremburg and Tokyo, which redefined the permissible party structures, claims, and fora of international litigation. ${ }^{64}$

The Allied victory in World War II triggered a remarkable change in the global legal order. The Allies self-consciously sought to transform international law from an interstitial, state-to-state system of narrow, informal customary rules based upon mutual respect and abstention- "do-no-harm" rules of neutrality and diplomatic immunity, for example - into an ambitious affirmative construct. The United Nations and the Bretton Woods systems heralded a postwar legal order based on institutionalism and constitutionalism: international institutions governed by multilateral treaties organizing cooperative assaults on all manner of global problems. ${ }^{65}$

Yet even as the postwar order dramatically expanded and codified international law, it reaffirmed international law's concern with individual rights and official responsibility. Tokyo and Nuremburg pierced the veil of state sovereignty and dispelled the myth that international law is for states only, re-declaring

63. Cf. Chicago \& S. Air Lines, Inc. v. Waterman Steamship Co., 333 U.S. 103, 111 (1948) ("IT]he very nature of executive decisions as to foreign policy is political, not judicial. . . . They are decisions of a kind for which the Judiciary has neither aptitude, facilities nor responsibility and which ha[ve] long been held to belong in the domain of political power not subject to judicial intrusion or inquiry.").

64. See Judgment of the Nuremburg Tribunal, 41 AM. J. INT'L L. 172 (1947) (holding major Nazi leaders guilty of crimes against humanity and rejecting, inter alia, the "superior orders" defense); T.I.A.S. No. 1589 (establishing Tokyo Tribunal).

65. These global "constitutions" sought both to allocate institutional responsibility and to declare particular rules of international law. Political conflict, for example, was to be regulated by the United Nations and its constituent organs-the Security Council, the Ceneral Assembly, and the International Court of Justice--under the aegis of a United Nations Charter premised on abstinence from unilateral uses of force. The United Nations system was supplemented by an alphabet soup of specialized, functional political organs and regional political and defense pacts based on respect for sovereignty and territorial integrity. Destructive economic conflicts, by contrast, were to be mitigated through the Bretton Woods system. The World Bank would supervise international reconstruction and development, the International Monetary Fund would monitor balance of payments, and the General Agreements on Tariffs and Trade (GATT) (which supplanted the stillborn International Trade Organization) would manage international trade in goods. Each institution was governed by a broadly worded charter that incorporated principles of economic liberalism and market capitalism. These global economic institutions were buttressed by regional economic communities such as the European Economic Communities, each governed by its own constitution-like treaty. 
that individuals are subjects, not just objects, of international law. ${ }^{66}$ Thereafter, private citizens, government officials, nongovernmental organizations and multinational enterprises could all be rightsholders and responsible actors under international law, and hence, proper plaintiffs and defendants in transnational actions. ${ }^{67}$ The war crimes tribunals secondly reaffirmed that courts-both international and domestic--are peculiarly appropriate fora for determining official rights and responsibilities for crimes against humanity. ${ }^{68}$ Third, Tokyo and Nuremberg galvanized the international human rights movement: the drive for global human rights standards that has provided transnational public law litigation with its authoritative texts. ${ }^{69}$

The war crimes trials transpired in ad hoc international tribunals. But after Nuremburg, several factors converged to shift transnational public law litigation out of international settings and into American courts. Ambitious proposals to create an international criminal court surfaced repeatedly, but to this day have never materialized. ${ }^{70}$ Evolving dispute-settlement regimes chose to grant

66. The law of nations had always punished piracy and slave trade, for example, as international crimes committed by individuals against individuals. For historical discussions of the role of the individual in international law, see, e.g., M. JANIS, supra note 19, at 163-74; Sohn, The New International Law: Protection of the Rights of Individuals Rather than States, 32 AM. U.L. REV. 1 (1982); Higgins, Conceptual Thinking About the Individual in International Law, 24 N.Y.L. SCH. L. REV. 11 (1978).

67. See generally Bowett, Claims Between States and Private Entities: The Twilight Zone of International Law, 35 CATH. U.L. REV. 929 (1986).

68. See generally Kahn, From Nuremberg to the Hague: The United States Position in Nicaragua v. United States and the Development of International Law, 12 YALE J. INT'L L. 1, 4-12 (1987); Cover, The Folktales of Justice: Tales of Jurisdiction, 14 CAP. U.L. REv. 179, 199 (1985). It is sometimes forgotten that American domestic courts were also involved in the war crimes adjudications during and after World War II. See, e.g., In re Yamashita, 327 U.S. 1 (1946) (refusing to intervene in military commission's conviction of Japanese commander for permitting his troops to commit atrocities in violation of the international laws of war); Ex Parte Quirin, 317 U.S. 1 (1942) (sustaining death penalty of seven German saboteurs, in part because charges against them stated violations of laws of war).

69. The principles stated in Section 6(c) of the Nuremberg Charter, for example, were reaffirmed and extended by the Genocide Convention. H. STEINER \& D. VAGTS, supra note 9, at 841; see also Steiner, The Youth of Rights, 104 HARV. L. REv. 917, 919 (1991) ("Two historical trends since World War II have given the human rights movement its authoritative texts: the 'universalization' of individual rights through their incorporation in constitutions of both new and older states, and their 'internationalization' through treaties and the related work of intergovernmental organizations.").

70. Proposals to create a permanent international criminal court have existed at least since World War I. See R. LILLICH, INTERNATIONAL HUMAN RIGHTS: PROBLEMS OF LAW, POLICY AND PRACTICE 910 (2d ed. 1991), Graefrath, Universal Criminal Jurisdiction and an International Criminal Court, 1 EUR. J. INT'L L. 67 (1990). Both the Genocide and the Anti-Apartheid Conventions would permit trial of offenders by an international penal tribunal, but no proposal has ever reached even the signature stage. $1 d$. at 914 . Congress has recently passed "sense of the Congress" resolutions urging the President to consider such a tribunal for drug traffickers and international terrorists. See Omnibus Diplomatic Security and Antiterrorism Act of 1986, Pub. L. No. 99-399, § 1201(a), 100 Stat. 853, 896 (1986); Anti-Drug Abuse Act of 1988, Pub. L. No. 100-690, $\$ 4108$ (a), 102 Stat. 4181, 4267 (1988). Recently, proponents have revived their proposals for such a court, urging that Saddam Hussein be tried for his atrocities in Iraq and Kuwait. See, e.g., EC Wants Saddam on Trial for War Crimes, Genocide, Wall St. J., Apr. 16, 1991, at 16, col. 3. Pursuant to the General Assembly's request in 1989, the International Law Commission has begun to develop a detailed proposal for such a court as part of its Draft Code of Crimes against the Peace and Security of Mankind. See McCaffrey, Current Developments: The Forty-Second Session of the International Law Commission, 34 AM. J. INT'L L. 930, 930-36 (1990). 
nonstate parties only limited direct access to international tribunals. ${ }^{71}$ Over time, the International Court of Justice failed to provide a meaningful forum for resolving international disputes, much less for enunciating international human rights norms or curbing national misconduct. ${ }^{72}$ Thus, after Nuremburg, global confidence in international adjudication steadily declined.

At about the same time, the American civil rights movement pressed international human rights norms into service in its war against racial discrimination. The first generation of modern transnational public lawsuits thus arose from the same social struggle that engendered its domestic counterpart. In October 1947, the NAACP filed an unsuccessful petition before the United Nations protesting the treatment of black Americans; four years later, the Civil Rights Congress filed a similarly unsuccessful petition charging that the United States government had committed genocide against blacks in violation of the Genocide Convention. ${ }^{73}$ While these petitions were pending, American civil liberties groups filed suits in both state and federal courts, citing the human rights provisions of the United Nations Charter and the Universal Declaration of Human Rights to challenge racial discrimination in education, transportation, employment, housing, and land ownership. ${ }^{74}$

These early cases created widespread concern that our new global treaty commitments, coupled with the Supremacy Clause, might undermine state sovereignty and domestic autonomy. ${ }^{75}$ In response, the courts fashioned two doctrines that frustrated this initial wave of suits. Numerous state and federal courts first invoked the doctrine of "nonself-executing treaties" to prevent individuals from directly enforcing the new positive law. ${ }^{76} \mathrm{By}$ its terms, the

71. Nonstate parties may appear, before, inter alia, the Iran-United States Claims Tribunal, the International Convention on the Settlement of Investment Disputes (ICSID), the European Court of Justice, and (with certain limitations) the European Court of Human Rights. See generally RESTATEMENT (THIRD), supra note 9 , at 393 .

72. See, e.g., R. FALK, REVIVING THE WORLD COURT 1-24 (1986) (describing decline in reliance upon international adjudicative processes since 1930); H. STEINER \& D. VAGTS, supra note 9, at 240-43 (describing the "World Court Crisis" of the 1970's and 80's); Rodley, Human Rights and Humanitarian Intervention: The Case Law of the World Court, 38 INT'L \& COMP. L.Q. 321 (1989) (discussing small number of ICJ rulings addressing human rights issues).

73. Dudziak, Desegregation as a Cold War Imperative, 41 STAN. L. REV. 61, 93-98 (1988).

74. See generally Lockwood, The United Nations Charter and United States Civil Rights Litigation: 1946-1955, 69 IOWA L. REV. 901 (1984); Tolley, Interest Group Litigation to Enforce Human Rights: Confronting Judicial Restraint, in WORLD JUSTICE? U.S. COURTS AND INTERNATIONAL HUMAN RIGHTS 123, 125 (M. Gibney ed. 1991).

75. These concerns spurred the unsuccessful drive to adopt the Bricker Amendment, which would have overruled Missouri v. Holland, 252 U.S. 416(1920). See generally D. TANANBAUM, THE BRICKER AMENDMENT CONTROVERSY: A TEST OF EISENHOWER'S POLITICAL LEADERSHIP (1988). Holland held that a statute implementing a migratory bird treaty could regulate matters apparently reserved to the states, notwithstanding the Tenth Amendment. Thus, under Holland, Congress would have had the authority to implement the Genocide Convention (had the United States ratified it) by enacting sweeping civil rights legislation. Fear of this result helped delay United States' ratification of the Genocide Convention for thirty-eight years; meanwhile, Congress ultimately enacted broad civil rights legislation anyway, invoking the commerce clause and section 5 of the Fourteenth Amendment.

76. See, e.g., Sei Fujii v. State, 38 Cal. 2d 718, 242 P.2d 617 (1952); Pauling v. McElroy, 278 F. 2d 252 (D.C. Cir. 1960) (individual may not invoke Charter to enjoin detonation of test nuclear weapons in 
Supremacy Clause makes treaties the supreme law of the land. ${ }^{77}$ It nowhere distinguishes between so-called self-executing treaties (which become part of domestic law immediately upon ratification) and nonself-executing treaties (which must be implemented by statute to acquire domestic legal effect). Nor did the Framers ever hint at such a distinction. ${ }^{78}$

Chief Justice Marshall first drew that line in Foster \& Elam v. Neilson, ${ }^{79}$ which declared that a treaty becomes the law of the land unless its terms "import a contract" or "either of the parties engages to perform a particular act," in which case legislative implementation is necessary "before it can become a rule for the Court." 80 Foster was reversed on its own facts only four years later and went largely ignored until the late nineteenth century. ${ }^{81}$ Moreover, Marshall clearly intended nonself-executing treaties to be the exception, not the rule. Nevertheless, post-Nuremburg courts revitalized and expanded the doctrine to hold a series of human rights treaties nonself-executing. ${ }^{82}$ Avoiding the sole relevant question-whether the plaintiff has stated a claim upon which relief can be granted-courts have fragmented the nonself-executing treaty doctrine into a series of preliminary obstacles that litigants must now overcome to enforce treaties through the courts. ${ }^{83}$

Marshall Islands); Vlissidis v. Anadell, 262 F.2d 398 (7th Cir. 1959) (alien may not resist deportation on ground that UN Charter superseded racist provisions of immigration laws). Ironically, before the California Supreme Court's decision in Sei Fujii, four Justices of the United States Supreme Court had joined concurring opinions suggesting that the California Alien Land Law-the statute at issue in Sei Fujii -violated United States' obligations under the United Nations Charter. See Oyama v. California, 332 U.S. 633, 647, 650 (1948) (Black, joined by Douglas, JJ. and Murphy, joined by Rutiedge, JJ., concurring).

77. See U.S. CONST. art. VI, $\$ 2$ ("[A]ll Treaties made or which shall be made, under the Authority of the United States, shall be the supreme law of the Land . . ..").

78. See generally Paust, Self-Executing Treaties, 82 AM. J. INT'L L. 760, 760-63 (1988) (reviewing Framers' views).

79. 27 U.S. (2 Pet.) 253 (1829).

80. Id. at 314 .

81. See United States v. Percheman, 32 U.S. (7 Pet.) 51 (1833) (Marshall, C.J.); Paust, supra note 78, at 772. Before Foster, the Court had routinely applied treaties as domestic law without considering whether or not they were nonself-executing. See, e.g., Martin v. Hunter's Lessee, 14 U.S. (1 Wheat.) 304 (1816). Furthermore, as Professor Henkin has observed, the Chief Justice's language in Foster has probably been misconstrued. See Henkin, supra note 10, at 866-67 n.65.

82. See cases cited supra note 76; see also Huynh Thi Ahn v. Levi, 586 F.2d 625, 629 (6th Cir. 1978) (declaring that articles of Geneva Convention Relative to Protection of Civilian Persons in Time of War and U.N. Declaration of Human Rights do not create private rights of actions for aliens in federal courts); In re Alien Children Educ. Litigation, 501 F. Supp. 544, 590 (S.D. Tex. 1980), aff'd mem. (5th Cir. 1981), aff'd on other grounds sub nom. Plyler v. Doe, 457 U.S. 202 (1982) (finding OAS Charter nonselfexecuting); Camacho v. Rogers, 199 F. Supp. 155, 158 (S.D.N.Y. 1961) (Article 55 of U.N. charter nonselfexecuting). But see Paust, supra note 78; Iwasawa, The Doctrine of Self-Executing Treaties in the United States: A Critical Analysis, 26 VA. J. INT'L L. 627, 685 (1986); Lillich, Invoking International Human Rights Law in Domestic Courts, 54 U. CIN. L. REv. 367, 372-85 (1985) (criticizing the doctrine).

83. In addition to asking whether the treaty is self-executing, courts have asked whether the plaintiff has standing to assert rights under a treaty, see, e.g., Diggs v. Schultz, 470 F.2d 461 (D.C. Cir. 1972), cert. denied, 411 U.S. 931 (1973); whether the international instrument confers rights on the plaintiffs, see, e.g., Diggs v. Richardson, 555 F.2d 848, 850 (D.C. Cir. 1976); or bestows a cause of action upon individuals, see, e.g., Tel-Oren v. Libyan Arab Republic, 726 F.2d 774, 808-10 (D.C. Cir. 1984) (Bork, J., concurring), cert. denied, 470 U.S. 1003 (1985). For a critique of these inquiries, see text accompanying infra notes 180199. 
The second judicial barrier to transnational public law litigation solidified in 1964, when the Court recast the Act of State doctrine into its modern form in Banco Nacional de Cuba v. Sabbatino. ${ }^{84}$ An odd coalition of the judicial restraint and anticolonialist elements on the Court formed an eight-Justice majority that voted not simply to defer to a Cuban expropriatory decree, but also to enforce it against an expropriated company's American owners. ${ }^{85}$ Although Sabbatino was technically a commercial case, replete with vertical elements, the Court declined even to apply international law to review the validity of the act of a recognized foreign sovereign fully executed within its own territory. ${ }^{86}$ By so saying, the Court went far beyond the comity rationale that had guided its previous Act of State decisions, now emphasizing separation of powers and judicial incompetence as the main reasons why American courts should not adjudicate cases under international law. ${ }^{87}$

By explicitly linking the Act of State Doctrine to separation of powers, Sabbatino implied that determinations regarding the legality of foreign state acts are quasi-political questions, whose decision is appropriately confided in the Executive Branch or Congress, not the courts. ${ }^{88}$ Moreover, the Court concluded that courts have limited competence to find the law in international cases, a conclusion belied both by Justice White's powerful dissent and extensive judicial precedents. ${ }^{89}$ Sabbatino especially urged abstention in customary

84. 376 U.S. 398 (1964).

85. See id. at 439 (White, J., dissenting) ("not only are the courts powerless to question acts of state proscribed by international law... they must render judgment and thereby validate the lawless act"). Among the majority, Justices Harlan (the author), Stewart, and Clark ranked as major proponents of judicial restraint; Justices Black, Douglas, Brennan, Goldberg, and Chief Justice Warren arguably fell within the egalitarian, anticolonialist camp.

86. Compare id. at 428 ("IT]he Judicial Branch will not examine the validity of a taking of property within its own territory by a foreign sovereign government, extant and recognized by this country at the time of suit, in the absence of a treaty or other unambiguous agreement regarding controlling legal principles, even if the complaint alleges that the taking violates customary international law.") (emphasis added), with Brilmayer, supra note 12, at 2299 ("Expropriation ... cases raise vertical issues [because they] involve a state's attempt to deprive persons of individual interests-property interests . . ..").

87. Had the Court simply_applied a comity rationale, it would have declined to enforce a Cuban decree that itself violated international law. As Professor McDougal later observed,

The vice in Sabbatino was, not in that it honored the act of a foreign State, but in that $i t$ honored

the act of a State in violation of international law. There is a genuine international law doctrine

of act of state, though the majority in Sabbatino did not seem to know about it, which requires

States to honor each other's acts, ... when within their jurisdiction and in accord with the

international law of responsibility of States. . . . It, however, completely frustrates the basic

purpose of this genuine doctrine of act of state ... if it is applied to secure the honoring of acts in violation of international law.

McDougal \& Jasper, The Foreign Sovereign Immunities Act of 1976: Some Suggested Amendments, in PRIVATE INVESTORS ABROAD-PROBLEMS AND SOLUTIONS IN INTERNATIONAL BUSINESS IN 1981, 1, $67-68$ (1981) (emphasis added).

88. Subsequently, several Justices took this position explicitly. See, e.g., First National City Bank v. Banco Nacional de Cuba, 406 U.S. 759, 785-90 (1972) (Brennan, J., dissenting); Alfred Dunhill of London, Inc. v. Republic of Cuba, 425 U.S. 682, 726-28 (1976) (Marshall, J., dissenting).

89. Compare Sabbatino, 376 U.S. at 425 (Act of State Doctrine is "concerned with a basic choice regarding the competence and finction of the Judiciary and the National Executive in ordering our relationships with other members of the international community") (emphasis added) with id. at 439-440 (White, J., dissenting) (expressing dismay "that the Court has, with one broad stroke, declared the ascertainment 
international law cases where no clear consensus exists on the content of the rule in question. ${ }^{90}$ Together with the self-executing treaty doctrine, Sabbatino thus cast a profound chill upon the willingness of United States domestic courts to interpret or articulate norms of international law-both customary and treatybased-in both private and public cases. ${ }^{91}$ By shifting ground from a comity/conflict-of-laws rationale to a separation-of-powers/political-question grounding, Sabbatino suggested that the doctrine's goal was less to protect foreign governments from embarrassment by requiring courts to recognize and enforce their acts as rules of decision than to protect the United States government from embarassment by requiring courts to abstain from meddling with executive branch decisionmaking in foreign affairs. By diminishing the role of the courts as declarers of international law, Sabbatino discouraged them "from playing important creative roles in determining common international standards," instead encouraging them to become "apologists for national policies determined by political aims of government." ${ }^{92}$ Furthermore, by emphasizing judicial incompetence to decide international law cases - even when private rights were at stake-Sabbatino undercut two of the most basic functions of an independent federal judiciary: to protect individuals against the power of the state and to ensure that government officials act in compliance with legal norms.

Sabbatino was decided at a time when activist courts were being urged to retrench, and to embrace "the passive virtues" in their domestic constitutional decisions. ${ }^{93}$ The courts soon read Sabbatino, together with earlier precedents regarding judicial deference to executive discretion in foreign affairs and

and application of international law beyond the competence of the courts. . . . [T] government seems to require such insulation from international law adjudications in its courts; and no other judiciary is apparently so incompetent to ascertain and apply international law").

Justice White's dissent, which repeatedly emphasized the judicial duty to decide cases in accordance with international law, bears striking parallels to the amicus curiae brief of the Executive Committee of the American Branch of the International Law Association. See Brief Amicus Curiae of the Executive Committee of the American Branch of the International Law Association at 7-22, 26-48, 52-56, Banco Nacional de Cuba v. Sabbatino, 376 U.S. 398 (1964). That brief was co-authored by Professor Myres McDougal of Yale Law School, who had previously taught both Justice White and Lee Albert, one of White's law clerks during the Court's 1963 term.

90. See Sabbatino, 376 U.S. at 428 ("[T]he greater the degree of codification or consensus concerning a particular area of international law, the more appropriate it is for the judiciary to render decisions regarding it, since the courts can then focus on the application of an agreed principle to circumstances of fact rather than on the sensitive task of establishing a principle not inconsistent with the national interest or with international justice.").

91. A computer-aided search reveals that American courts have cited Sabbatino nearly five hundred times since its decision, as compared to only forty citations to The Paquete Habana, see supra note 54, which was decided more than sixty years earlier.

92. M. KaPlan \& N. KatzenBaCH, THE POLITICAL Foundations of INTERNATIONAL LaW 270 (1961): see also Franck, International Law: Through National or International Courts?, \& VILL. L. REV. 139, 150 (1962-63) ("When the courts feel themselves obliged to defer to the executive, they no longer 'truly and impartially minister justice,' nor do they minister international law properly so-called.") (emphasis in original).

93. See Bickel, The Supreme Court, 1960 Term-Foreword: The Passive Virtues, 75 HaRV. L. REv. 40,51 (1961). 
political question notions imported from the domestic electoral context, as a general directive to stay out of foreign affairs adjudication. ${ }^{94}$ This chill stimulated a period of American judicial withdrawal from the arena of public international norm-enunciation that lasted for more than a decade.

This judicial paralysis reached its peak during the Indochina war, when American courts consistently - and in some cases, unjustifiably - turned away challenges to that conflict's constitutionality and international legality. ${ }^{95}$ To some, this "restraint" amounted to "judicial complicity in the crimes of Vietnam." ${ }^{96}$ Nevertheless, the image of judicial diffidence in the face of governmental violence became imprinted upon the consciousness of a generation as "business as usual." reached maturity unaware of America's rich judicial history of applying international law and inclined to accept the recent status quo of judicial deference as normatively desirable.

As the 1970's closed, however, two complementary trends engendered a new generation of transnational public law cases in United States judicial fora. The first was the by now well-chronicled rise of domestic public law litigation: a growing acceptance by litigants of United States courts as instruments of social change. ${ }^{98}$ At the domestic level, the federal courts oversaw the rise of

94. See, e.g., Chicago \& S. Air Lines, Inc. v. Waterman S.S. Corp., 333 U.S. 103 (1948); Baker v. Carr, 369 U.S. 186 (1962).

95. For a listing of the Vietnam cases, see $\mathrm{H}$. KOH, supra note 1 , at $296 \mathrm{n} .49$. For analyses of the unconstitutionality and international illegality of various aspects of the Indochina conflict, see generally Ely, The American War in Indochina, Part II: The Unconstitutionality of the War They Didn't Tell Us About, 42 STAN. L. REV. 1093 (1990); Velvel, The War in Viet Nam: Unconstitutional, Justiciable, and Jurisdictionally Attackáble, 16 U. KAN. L. REV. 449 (1968): THE ConsulTaTIVE COUNCIL OF THE LAWYERS COMMITTEE ON AMERICAN POLICY TOWARDS VIETNAM, VIETNAM AND INTERNATIONAL LAW (1990).

96. R. COVER, JUSTICE ACCUSED Xi (1975); accord, Cover, The Supreme Court, 1982 Term-Foreword: Nomos and Narrative, 97 HARV. L. REV. 4, 57 (1983) ("The jurisdictional principles of deference are problematic precisely because, as currently articulated by the Supreme Court, they align the interpretive acts of judges with the acts and interests of those who control the means of violence."). Although Professor Ely, among others, concludes that President Nixon should have been impeached for the secret, unauthorized bombing of Cambodia, Ely, supra note 95, at 1146-48, he further suggests that in an appropriate lawsuit, the Vietnam-era courts could have "'remand[ed]' to Congress so that it [could] do its constitutional duty and decide whether the war in question should continue." Id. at 1135; cf. Dellums v. Bush, 752 F. Supp. 1141,1149 (D.D.C. 1990) ("in principle, an injunction may issue at the request of Members of Congress to prevent the conduct of a war which is about to be carried on without congressional authorization"). My colleague Owen Fiss has suggested to me that some Supreme Court justices hesitated to take such a step for fear of undermining the Court's domestic advances in the area of civil rights. Justice Potter Stewart, however, later concluded that the Supreme Court's failure to decide the legality of the Vietnam conflict had been its greatest failure during his tenure. See Tribe, Justice Stewart: A Tale of Two Portraits, 95 YALE L.J. 1328, 1331 (1986); see also Koh, Commentary: The Liberal Constitutionalism of Justice Douglas, in "He Shall Not Pass This Way Again:" The legacy of Justice William O. Douglas 297, 301 \& n.18 (S. Wasby ed. 1990) (reviewing Justice Douglas' opinions calling for judicial review of the legality of the Indochina conflict).

97. Cf. Roskin, From Pearl Harbor to Vietnam: Shifting Generational Paradigms and Foreign Policy, 89 POL. SCI. Q. 563 (1974) (generation's formative experiences establish its dominant normative paradigms, which are not supplanted until arrival of new generation).

98. Two famous articles capture the social goals and functions of this changing domestic conception of the role of the courts. See Chayes, The Role of the Judge in Public Law Litigation, supra note 4; Fiss, The Supreme Court, 1978 Term-Foreword: The Forms of Justice, 93 HARV. L. REv. 1 (1979). 
the "new" equal protection, the civil and criminal due process revolutions, 99 and the growing accountability of government officers for officially inflicted injuries through the decline of sovereign immunities and the growth of the Bivens doctrine and Section 1983 litigation. ${ }^{100}$ These trends fostered judicial creation of an American law of "constitutional torts." greater public acceptance of the notion that federal courts may-and indeed should-restructure wrongful systems, such as schools, prisons, and hospitals, and increased confidence in the courts' ability and expertise to engage in such reform. The debate over the new "public action" addressed many of the concerns about separation of powers, judicial competence, and the "countermajoritarian difficulty" currently raised against transnational public law litigation. ${ }^{102}$

This growing faith in the capacity of the courts to engage in domestic public law litigation coincided with a second trend: the explosion of transnational commercial litigation in United States courts. As nations increasingly entered the marketplace, and the United States adopted the doctrine of restrictive sovereign immunity by statute, ${ }^{103}$ federal courts became increasingly obliged to adjudicate commercial suits brought by individuals and private entities against foreign governments. ${ }^{104}$ This plethora of transnational suits not only returned domestic courts to the business of adjudicating international law, from which they had largely excluded themselves since Sabbatino, but also stimulated a reawakening of the bench's and bar's interest in the black-letter doctrine of international and foreign relations law. ${ }^{105}$

The resurgence of transnational private law litigation forced reevaluation of the comity, separation-of-powers, and incompetence rationales for judicial abstention in transnational public law cases. The persistent question arose, "if contracts, why not torture?" If American courts could subject the commercial conduct of foreign sovereigns to legal scrutiny without offending comity, why should comity immunize that same sovereign from judicial examination of its egregious public conduct? These precedents also cast doubt upon Sabbatino's separation-of-powers conclusion that the lawfulness of foreign governmental acts is a quasi-political question, which courts may not constitutionally decide. If a court could hold a foreign sovereign defendant in violation of a commercial

99. See, e.g., Goldberg v. Kelly, 397 U.S. 254 (1970); Miranda v. Arizona, 384 U.S. 436 (1966).

100. See generally J. MASHAW \& R. MERRILL, INTRODUCTION TO THE AMERICAN PUBLIC LAW SYSTEM 783-934 (2d ed. 1985).

101. See generally P. SCHUCK, SUING GOVERNMENT (1983); Whitman, Constitutional Torts, $79 \mathrm{MICH}$. L. REV. 69 (1980).

102. See generally Fletcher, The Discretionary Constitution: Institutional Remedies and Judicial Legitimacy, 91 YALE L.J. 635 (1982). Although this trend has been controversial, it has hardly abated. See, e.g., Missouri v. Jenkins, 110 S. Ct. 1651 (1990) (permitting federal judge to authorize property tax increase violative of state law).

103. See Foreign Sovereign Immunities Act of 1976, 28 U.S.C. $\S \S 1330,1602-1611$ (1988).

104. One measure of this trend is that United States courts have cited the Foreign Sovereign Immunities Act of 1976 in nearly 600 cases since it became law.

105. That interest helped trigger the legal community's call in the late 1970's for the RESTATEMENT (THIRD) OF FOREIGN RELATIONS LAW, cited in supra note 9. 
contract without usurping the executive function, why couldn't it hold the same defendant in violation of a human rights treaty, or a clearly defined jus cogens norm against torture? ${ }^{106}$ Finally, these commercial rulings dispelled the selffulfilling belief-increasingly accepted since Vietnam-that domestic courts inherently lack the competence to manage or decide complex international law cases. If private litigants could conduct massive overseas discovery and adduce probative facts regarding a foreign state's commercial conduct, what rendered them incompetent to do the same with regard to a foreign state's heinous treatment of its own citizens? If a court could evaluate the "reasonableness" of the extraterritorial assertion of American regulatory laws or find a foreigner's minimum contacts with a forum sufficient to satisfy "due process," why couldn't the same court construe far less ambiguous terms in a human rights treaty? The growing codification and hence, accessibility of customary international law rules-through statutes, unratified treaties, and scholarly treatises-belied the claim that such rules were hopelessly beyond a domestic court's law-finding capacities. ${ }^{107}$ These factors-and not the horizontal/vertical distinction-ultimately explain the courts' return to regular adjudication of the expropriation, extraterritoriality, treaty, and human rights cases to which Professor Brilmayer points. ${ }^{108}$

In 1980, these trends came together in the Second Circuit's landmark decision in Filartiga v. Peña-Irala, which inaugurated the era of transnational public law litigation in which we now live. ${ }^{109}$ In Filartiga, transnational public law litigants finally found their Brown $v$. Board of Education. ${ }^{110}$ Supported

106. One recent signal of the Court's shift on this matter is its first Act of State case in nearly fifteen years, W.S. Kirkpatrick Co. v. Environmental Tectonics Corp., 110 S. Ct. 701 (1990). In Kirkpatrick, the Court unanimously modified its position in Sabbatino, now declaring that the Act of State doctrine is not a general rule of abstention in cases that may embarrass foreign governments, but a federal choice-of-law rule that applies only when the validity of a foreign sovereign act is at issue. $I d$. at 707. It is noteworthy that Kirkpatrick's narrowing of the Act of State Doctrine was authored by Justice Scalia, who is not only one of the Court's leading exponents of separation of powers, but who had also (as a private attorney) urged application of the Act of State doctrine in International Ass" $n$ of Machinists v. OPEC, 649 F.2d 1354, 1355 (9th Cir. 1981), cert. denied, 454 U.S. 1163 (1982).

107. In addition to detailed statutory codifications of international law rules, such as the Foreign Sovereign Immunities Act of 1976, supra note 103, domestic courts may now refer to authoritative treatises such as RESTATEMENT (THIRD) OF FOREIGN RELATIONS LAW, supra note 9, and the International Law Commission's emerging draft reports on various aspects of international law, see, e.g., McCaffrey, supra note 70. Domestic courts may now also refer to a growing body of what Hiram Chodosh has called "declarative international law." This body comprises rules "that are declared as law by a majority of states," usually in unratified treaties or other legal texts (e.g., certain provisions of the United Nations Law of the Sea Convention), "but not actually enforced by them, or rules that are both practiced and accepted as law, but only by a minority of states." Chodosh, Neither Treaty nor Custom: The Emergence of Declarative International Law, 26 TEX. INT'L L.J. 87, 89 (1991).

108. Brilmayer, supra note 12 , cases cited in notes 37-61. In my view, they also explain the steady erosion of the Act of State Doctrine since Sabbatino. See generally RESTATEMENT (THIRD), supra note 9, $\$ \S 443-44$ (describing current contours of the doctrine). Even before the Court's recent decision in Kirkpatrick, the Act of State Doctrine had come to rival the hearsay rule for exceptions. See generally Bazyler, Abolishing the Act of State Doctrine, 134 U. PA. L. REv. 325, 368-75 (1986) (enumerating these exceptions).

109. 630 F.2d 876 (2d Cir. 1980).

110. 347 U.S. 483 (1954). 
by an important government amicus brief pressing the Carter Administration's human rights policy, ${ }^{111}$ Filartiga held that the Alien Tort Statute conferred district court jurisdiction over a suit by Paraguayans versus a Paraguayan official who had tortured their relative to death in Paraguay, while acting under color of governmental authority. On remand, the federal district court awarded judgment of nearly $\$ 10.4$ million, comprising compensatory damages based on Paraguayan law and punitive damages based on United States cases and international law. ${ }^{112}$

Filartiga convincingly rebutted the comity, separation-of-powers, and incompetence objections to domestic judicial decision of human rights cases. The court showed no disrespect to Paraguay by trying Peña-Irala because his acts were illegal even under Paraguayan law. ${ }^{113}$ " [F]or purposes of civil liability," the court declared, "the torturer has become-like the pirate and slave trader before him-hostis humani generis, an enemy of all mankind."114 By so saying, the Second Circuit reaffirmed the Nuremburg ideal: that torture (like genocide) is never a legitimate instrument of state power. Thus, official torturers may not invoke comity or cloak themselves in state sovereignty to avoid individual responsibility to their victims before a court of law.

Nor did the Filartiga court offend separation of powers. Even if the Executive Branch had not supported adjudication, the core issue in the case was quintessentially legal: whether the victims had a right to be free from torture that was actionable in federal court. ${ }^{115}$ Resolution of that question required standard legal determinations-judicial construction of the Alien Tort Statute and human rights treaties-and a conclusion that the customary international law norm against torture was definable, obligatory, and universal. Such legal determinations, as Professor Brilmayer correctly notes, did "not necessarily entail the formulation of foreign policy."116 Finally, in Filartiga, judicial incompetence was not seriously at issue. All parties were before the court, the overseas factfinding required was not extraordinary, and no difficult choice-oflaw questions were raised because American, Paraguayan, and international law all condemned torture. ${ }^{117}$ Moreover, Filartiga's ruling on remand, which created a federal common law remedy against torture, fell squarely within Sabbatino's recognition that issues "in ordering our relationships with other members of the international community must be treated exclusively as an

111. Memorandum for the United States as Amicus Curiae, Filartiga v. Peña-Irala, 630 F.2d 876 (2d Cir. 1980), reprinted in 19 I.L.M. 585 (1980) [hereinafter U.S. Filartiga Memorandum].

112. Filartiga v. Peña-Irala, 577 F. Supp. 860, 864-67 (E.D.N.Y. 1984).

113. See U.S. Filartiga Memorandum, supra note 111 , at 605 .

114. Filartiga, 630 F.2d at 890 .

115. Id. at 885 .

116. Brilmayer, supra note 12, at 2307.

117. See U.S. Filartiga Memorandim, stupra note 111, at 605 . 
aspect of [post-Erie] federal [common] law," made by the federal courts, binding on the states, but subject to legislative revision. ${ }^{118}$

Since Filartiga, transnational public law litigation has followed two tracks: cases brought by individual plaintiffs and those brought by nation-states. The individual suits may themselves be subdivided into "international tort" suits, in which plaintiffs have sought compensation, norm-enunciation, and deterrence through judicial declarations of international law violations, and more ambitious "institutional reform" suits, in which plaintiffs have sought not simply retrospective redress and prospective declarations, but affirmative reform of United States foreign policy programs.

International tort suits have generated the greatest activity in United States courts. Filartiga provided the paradigm for a series of Alien Tort Statute suits by alien plaintiffs against foreign officials acting under color of governmental authority, claiming violations of the plaintiffs' internationally recognized human rights. ${ }^{119}$ Although no Filartiga-type plaintiff has apparently collected full compensation for his injuries, many have expressed satisfaction simply to have won default judgments announcing that the defendant had transgressed universally recognized norms of international law. ${ }^{120}$ These small successes encour-

118. Banco Nacional de Cuba v. Sabbatino, 376 U.S. 398,425 (1964). In effect, the district judge treated the Alien Tort Statute as statutory authority to create a specialized federal common law of "torts only committed in violation of the law of nations," analogous to that created by the federal courts in the area of collective bargaining contracts after Textile Workers Union of America v. Lincoln Mills, 353 U.S. 448 (1957) (reading grant of federal jurisdiction in \$301(a) of the Taft-Hartley Act, 29 U.S.C. § 185(a) (1988), as authorizing federal courts to fashion federal common law of labor-management). The district judge's ruling can be viewed as valid both under Lincoln Mills' theory of "delegated" federal common lawmaking authority and Sabbatino's notion of a "federal common law of international relations." See Merrill, The Common Law Powers of Federal Courts, 52 U. CHI. L. REv. 1, 7, 35 (1985) (using these terms); Field, Sources of Law: The Scope of Federal Common Law, 99 HARV. L. REV. 881, 934-42, 953 (1986). See also infra text accompanying notes 189-99.

119. See, e.g., Tel-Oren v. Libyan Arab Republic, 726 F.2d 774 (D.C. Cir. 1984), cert. denied, 470 U.S. 1003 (1985) (Israelis versus Palestine Liberation Organization); Forti v. Suarez-Mason, 672 F. Supp. 1531 (N.D. Cal. 1987), modified, 694 F. Supp. 707 (N.D. Cal. 1988) (Argentinian torture victims versus former Argentinian general); Trajano v. Marcos, Nos. 86-2448, -2449, -2496, 87-1707 (9th Cir. July 10, 1989) (per curiam) (unpublished) (Filippino torture victims versus former Philippine President): Paul v. Avril, No. 91-0399 (S.D. Fla. filed Feb. 28, 1991) (Haitian torture victims versus former Haitian President); Xuncax v. Gramajo, No. 91-11564WD (D. Mass. filed June 6, 1991) (Guatemalan victims of torture and summary execution versus former Guatemalan Defense Minister). See generally Randall, Federal Jurisdiction over International Law Claims: Inquiries into the Alien Tort Statute, 18 N.Y.U. J. INT'L L. \& POL. 1, 5-6 nn.17 \& 19 (1985) (collecting post-Filartiga Alien Tort Statute cases).

120. See, e.g., Panel on Civil Remedies Against Terrorists and Nations Supporting Terrorists, American Bar Association National Conference on the Law in Relationship to Terrorism (June 6, 1986) (remarks of Steven Schneebaum) (verbatim remarks on file with author) ("Even if it's the case ... that a lawsuit against a terrorist is ultimately not effective to get real money damages for a plaintiff who has been injured, it may still result that after cases like [Tel-Oren], it will be that much more difficult for terrorists to find safe haven in the United States to be protected from their victims ...."); Gerstel \& Segall, Conference Report: Human Rights in American Courts, 1 AM. U.J. INT'L L. \& POL'Y 137, 143 (1986) (quoting statement of human rights lawyer) ("Where the President is aiding in the torture of others, we want the judiciary to be able to come in against the President. The purpose of continuing lawsuits . . . therefore, is to attempt to bring the action into a legal context. It is necessary to create a means for dialogue even if you know you are going to lose."). 
aged Alien Tort Statute plaintiffs to expand the class of defendants beyond foreign government officials to a second group, foreign governments. ${ }^{121}$

Foreign nationals, frequently joined by United States citizens and Members of Congress, began to sue a third class of defendants-the United States government and its executive officials ${ }^{122}$ _charging, for example, that the Reagan Administration's support of the contras ${ }^{123}$ and its policy of detaining Cuban and Haitian refugees ${ }^{124}$ contravened treaties or customary international law. Like domestic institutional reform litigants, who have sought judicial reform of prisons, school systems, and the like, these transnational litigants have sought to use domestic adjudication to reform United States foreign policy. These suits have generally failed in obtaining relief. But as in the international tort suits, the plaintiffs have sought not so much to win judgments as to obtain judicial declarations calling American officials to account for their alleged failure to obey international law.

In each type of case, individual plaintiffs have sued governments and government officials in domestic courts, claiming that they have been victimized by international wrongs. Although their announced aim has been retrospective redress, the underlying focus of their actions has been prospective: to provoke a judicial declaration that the conduct of United States or foreign government officials violates a norm of international law. To the extent that plaintiffs have won such judicial declarations, they have sought to use them primarily as political constraints upon the defendants' future conduct.

The most novel development in transnational public law litigation has been its expansion beyond individual to state plaintiffs. The litigation brought by the Government of India against Union Carbide in United States and Indian courts

121. See. e.g., Amerada Hess Shipping Corp. v. Argentine Republic, 488 U.S. 428 (1989) (suit by Liberian corporations against Argentina arising out of bombing of oil tanker during Falklands war); Von Dardel v. Union of Soviet Socialist Republics, 623 F. Supp. 246 (D.D.C. 1985), vacated, 736 F. Supp. 1 (D.D.C. 1990); Siderman v. Republic of Argentina, No. CV 82-82-1772-RMT (MCx) (C.D. Cal. Mar. 7, 1985), appeal pending (action by Argentine citizens against Argentina for claims of torture; $\$ 2.6$ million default judgment vacated after reconsideration on grounds of foreign sovereign immunity); DeNegri v. Republic of Chile, No. 86-3805 (D.D.C. 1990) (similar suit against Chile).

122. See, e.g., Sanchez-Espinoza v. Reagan, 770 F. $2 d 202$ (D.C. Cir. 1985) (suit by twelve Nicaraguans, twelve Congressmen, and two Americans challenging United States policy in Nicaragua); Greenham Women Against Cruise Missiles v. Reagan, 755 F.2d 34 (2d Cir. 1985) (suit brought by association of British women, United States citizen living in England, and two Congressmen challenging legality of United States' deployment of cruise missiles in Great Britain); Chaser Shipping Corp. v. United States, 649 F. Supp. 736 (S.D.N.Y. 1986), aff"d mem.. 819 F.2d 1129 (2d Cir. 1987), cert. denied, 484 U.S. 1004 (1988) (suit by foreign shipowner seeking $\$ 1.6$ million in damages from United States for striking a mine laid by United States in Nicaraguan harbor).

123. See, e.g., Sanchez-Espinaza, 770 F.2d 202 (D.C. Cir. 1985); Ramirez de Arellano v. Weinberger, 724 F.2d 143 (D.C.Cir. 1983), rev"d, 745 F.2d 1500 (D.C. Cir. 1984) (en banc), vacated and remanded for reconsidcration in light of subseguent legislation, 471 U.S. 1113 (1985) (challenging alleged occupation of plaintiffs' Honduran land for use as training facility).

124. Sec, e.g., Garcia-Mir v. Meese, 788 F.2d 1446 (11 th Cir.), cert. denied, 479 U.S. 889 (1986); Jean v. Nelson, 727 F.2d 957 (11th Cir. 1984) (en banc), aff $d, 472$ U.S. 846 (1985); Palma v. Verdeyen, 676 F.2d 100 (4th Cir. 1982): Rodriguez-Fernandez v. Wilkinson, 654 F.2d 1382 (10th Cir. 1981); Haitian Refugee Center v. Gracey, 600 F. Supp. 1396 (D.D.C. 1985), aff d on other grounds, 809 F.2d 794 (D.C. Cir. 1987); Orantes v. Smith. 541 F. Supp. 351 (N.D.Cal. 1982). 
in the wake of the Bhopal tragedy provides the most dramatic example. ${ }^{125}$ Following an environmental disaster, the importing state sued a private multinational entity in domestic, rather than international, court, making complex claims based on transnational law. ${ }^{126}$ India sued as parens patriae for its citizens, claiming to seek judicial reparations for their injuries, but its apparent motive in turning to American courts was not so much to win enforceable relief, as to obtain a judicial declaration of Union Carbide's strict liability for the disaster. Although India hoped to use such a declaration to provoke a political settlement that would potentially bind Union Carbide, India, the United States, as well as the private Indian plaintiffs, that ambition was not realized.

Following suit, the Government of Nicaragua threatened to sue the United States in American courts to enforce a judgment it had previously obtained from the International Court of Justice. ${ }^{127}$ Shortly thereafter, the Republic of the Philippines sued its own former dictator, Ferdinand Marcos, in an American

125. For descriptions of the legal issues raised by the tragedy, see generally Symposium. The Bhopal Tragedy, 20 TEX. INT'L L.J. 267 (1985); Koh, Importer State Responsibility, stupra note 1. The facts of the Bhopal tragedy are well-known. In December 1984, highly toxic methyl isocyanate gas leaked from a pesticide factory located in Bhopal, India, killing more than 2,000 Indian citizens and injuring at least 200,000 others. The Union of India and private plaintiffs filed suit against Union Carbide in American courts. In a May 1986 order that was largely upheld on appeal, a United States district judge dismissed the suits on grounds of formm non conveniens, subject to certain conditions. See In Re Union Carbide Corp. Gas Plant Disaster at Bhopal, India in December, 1984, 634 F. Supp. 842 (S.D.N.Y. 1986), aff'd in part, 809 F.2d 195 (2d Cir. 1987). In September 1986, India and the State of Madhya Pradesh then sued Union Carbide in a Bhopal district court. In February 1989, pursuant to a settlement promoted by a five-judge bench of the Indian Supreme Court, Union Carbide paid $\$ 470$ million to the Indian government. Most of that money has gone into Indian government bonds, with less than $\$ 5$ million actually reaching individual Indian beneficiaries. The present Indian government repudiated the settlement and the beneficiaries petitioned the Indian Supreme Court to reopen the case. In October 1991, the Court upheld the civil settlement, but lifted immunities against criminal prosecution. See Gargan, Settlement on Bhopal is Accepted, N.Y. Times, Oct. 4, 1991, at D4, col. 1 .

126. In the United States and India, the plaintiffs offered a novel theory of "multinational enterprise liability." They claimed that, notwithstanding traditional notions of limited shareholder liability, a parent multinational corporation that controls a majority interest in a foreign subsidiary that in turn runs a hazardous production facility has a nondelegable duty to assure that the activity causes no harm. See Union of India's Complaint, reprinted in Mass Disasters aNd Multinational Liability: THE BHOPAL CASE 1 (U. Baxi \& T. Paul eds. 1986). Although plaintiffs attempted to use this theory as a novel way to pierce the corporate veil under domestic law, some arguments have been made that such a theory could be justified by international law, such as international codes of conduct directed at guiding the conduct of multinational enterprises. See Westbrook, Theories of Parent Company Liability and the Prospects for International Settlement, 20 TEX. INT'L L.J. 321, 326-27 (1985).

127. Military and Paramilitary Activities (Nicar. v. U.S.), 1986 I.C.J. Rep. 14 (June 27). Nicaragua's counsel initially declared that they would attempt to enforce the World Court's judgment directly in United States courts. See N.Y. Times. June 28. 1986. at A4, col. 4: Effron, Nicaragua Likely to Press on Ruling, Nat'l L. J., July 14, 1986, at 3, col. 1. In the end, however, the only domestic enforcement action was brought by U.S. citizens and organizations. Sec Committee of United States Citizens Living in Nicaragua v. Reagan, 859 F.2d 929 (D.C. Cir. 1988). See generally O'Connell, The Prospects for Enforcing Monetary Judgments of the International Court of Justice: A Study of Nicaragua's Judgment Against the United States, 30 VA. J. INT'L L. 891. 913-27 (1990). 
court, charging him with violations of the RICO statute. ${ }^{128}$ More recently, the Panamanian government filed a similar civil action against Manuel Noriega. ${ }^{129}$

Transnational public law litigation thus constitutes a novel and expanding effort by both state and individual plaintiffs to fuse international legal rights with domestic judicial remedies. Transnational litigation, which originated in the context of private commercial suits against foreign governments, has now migrated into the realm of public human rights suits against the United States and foreign governments and officials. State-initiated litigation, once restricted to international tribunals, has also migrated into American courts, reflecting failing faith in international adjudication as a process for obtaining meaningful remedies.

To summarize, transnational public law litigation is characterized by: (1) a transnational party structure, in which states and nonstate entities equally participate; (2) a transnational claim structure, in which violations of domestic and international, private and public law are all alleged in a single action; (3) a prospective focus, fixed as much upon obtaining judicial declaration of transnational norms as upon resolving past disputes; (4) the litigants' strategic awareness of the transportability of those norms to other domestic and international fora for use in judicial interpretation or political bargaining; ${ }^{130}$ and (5) a subsequent process of institutional dialogue among various domestic and international, judicial and political fora to achieve ultimate settlement.

These five features lie at the core of the phenomenon. To be sure, different classes of transnational litigants emphasize different goals. International tort plaintiffs pursue not only norm-enunciation, but also compensation, deterrence, and denial of safe haven to the defendant. Institutional reform plaintiffs addi-

128. Republic of Philippines v. Marcos, 862 F.2d 1355 (9th Cir. 1988), cert. denied, 490 U.S. 1035 (1989) (en banc) (charging Marcos with violation of Racketeer Influenced Corrupt Organizations Act (RICO), 18 U.S.C. $§ 1961-1968$ (1988)); Republic of Philippines v. Marcos, 806 F.2d 344 (2nd Cir. 1986), cert. denied sub nom. Ancor Holdings, N.V. v. Republic of Philippines, 480 U.S. 942 (1987) (suit to recover Marcos' New York apartment buildings). Although the Marcos suits revolved around questions of American law, those questions were closely intertwined with international law issues regarding the extraterritorial reach of the RICO statute, the civil and criminal immunities of ex-heads of state, and the like. Furthermore, though the current Phillippine government undeniably seeks retrospective redress, its actions appear strongly motivated by the prospective political aim of solidifying its own standing by exposing its predecessor's illegal conduct.

129. Johnston, Panamanians File Suit Against Noriega Seeking $\$ 6.5$ Billion, N.Y. Times, Oct. 25, 1990 , at $A 21$, col. 1 .

130. Upon filing Nicaragua's suit against the United States before the International Court of Justice, Abram Chayes urged the Court to indicate "provisional measures of interim protection" under Article 41 of the Court's statute-an order preserving the status quo pending the Court's resolution of the merits of the case. The Court unanimously indicated its interim protection order in May 1984, which included a directive that the United States immediately cease from mining Nicaraguan harbors. Military and Paramilitary Activities (Nicar. v. U.S.), 1984 I.C.J. 169 (Interim Order of May 10), reprinted in 25 I.L.M. 1023 (1986). Shortly thereafter, Congress cut off further aid to the contras, based upon a conviction by some members that international law had been violated. See D. MOYNIHAN, ON THE LAW OF NATIONS 141-47(1990). When told about the congressional action, Chayes reportedly said, "We just got our provisional measures from Congress." $C f$. Committee of United States Citizens Living in Nicaragua v. Reagan, 859 F.2d 929 (D.C. Cir. 1988) (private suit charging, imer alia, that Reagan Administration's noncompliance with World Court judgment violated Fifth Amendment and Administrative Procedure Act). 
tionally seek revision of governmental policies; and state plaintiffs pursue national and geopolitical objectives. Similarly, although the most prominent transnational public lawsuits have recently proceeded before United States courts, nothing about the phenomenon requires that it be confined to this domestic forum. ${ }^{131}$ Yet since Nuremburg and Tokyo, its essence has remained unchanged: the coupling of a substantive notion-individual and state responsibility-with a familiar process-adjudication-and a normative goal-the promotion of universal norms of international conduct.

Whether transnational public law litigation in United States courts will flourish or fail remains to be seen. Although the Supreme Court has not squarely considered the Alien Tort Statute in the Filartiga context (an alien suing a foreign government official), in Amerada Hess Shipping Corp. $v$. Argentine Republic ${ }^{132}$ the Court held that the Foreign Sovereign Immunities Act (FSIA) provides the sole basis for obtaining jurisdiction over a foreign state in a U.S. court, even if the plaintiff alleges jurisdiction under the Alien Tort Statute. Although Amerada Hess specifed that "[t]he Alien Tort Statute . . . of course has the same effect after the passage of the FSIA as before with respect to defendants other than foreign states," its ruling has chilled international tort suits against foreign sovereigns. ${ }^{133}$ Recent D.C. Circuit rulings upholding dismissals of Alien Tort actions in Tel-Oren v. Libyan Arab Republic (particularly Judge Bork's controversial concurring opinion) ${ }^{134}$ and Saltany $v$. Reagan ${ }^{135}$ have further discouraged transnational public law litigants. Meanwhile, stung by institutional reform suits against its foreign policy, in Trajano

131. The Bhopal litigation, for example, proceeded in the courts of India, and may yet return to United States courts (perhaps on an Indian suit seeking to enforce a criminal judgment of an Indian court against Union Carbide or its officials). See supra note 125.

132. 488 U.S. 428 (1989).

133. Id. at 438. Cf. Von Dardel v. Union of Soviet Socialist Republics, 736 F. Supp. 1 (D.D.C. 1990) (vacating and remanding Alien Tort suit against U.S.S.R. after Amerada Hess). By requiring suits against foreign sovereigns to proceed under the FSIA, however, Amerada Hess has not affected traditional Filartiga suits against individual officials. See. e.g., Forti v. Suarez-Mason, No. C-87-2058 (N.D. Cal. Apr. 25, 1990) (post-Amerada Hess award of nearly eighty million dollar default judgment against Argentinian general). Nor has Amerada Hess foreclosed the possibility that plaintiffs could still win judgments against foreign states by invoking one or more of the FSIA's exceptions to immunity. See, e.g., Belsky, Merva \& RohtArriaza, Implied Waiver Under the FSIA: A Proposed Exception to Immunity for Violations of Peremptory Norms of International Law, 77 CAL. L. REV. 365 (1989) (arguing that even after Amerada Hess, suits alleging violations of jus cogens norms can be brought under the FSIA itself).

134. 776 F.2d 774, 798 (D.C. Cir. 1984) (Bork, J., concurring), cert. denied, 470 U.S. 1003 (1985) (dismissing suit by Israeli torture and terrorism victims against the Palestine Liberation Organization). For critiques of that opinion, see Koh, supra note $\dagger$, at 202-08; D'Amato, What Does Tel-Oren Tell Lawyers? Judge Bork's Concept of the Law of Nations is Seriously Mistaken. 79 AM. J. INT'L L. 92 (1985). See also infra text accompanying notes 170 - 179 (discussing Tel-Oren).

135. 702 F. Supp. 319 (D.D.C. 1988), aff d, 886 F.2d 438 (D.C. Cir. 1989), cert. denied, 110 S. Ct. 2172 (1990) (upholding award of FED. R. CIV. P. II sanctions against transnational litigants who sued for damages arising out of U.S. government raid on Qaddafi's headquarters in Libya); see also D'Amato, The Imposition of Attorney Sanctions for Claims Arising From the U.S. Air Raid on Libya, 84 AM. J. INT'L L. 705 (1990) (criticizing decision). 
v. Marcos, ${ }^{136}$ the Reagan Justice Department reversed the Carter Administration's position, which had read the Alien Tort Statute to authorize Filartigatype actions. The Bush Administration, at this writing, has yet to choose between the Carter and Reagan readings of the statute. ${ }^{137}$

Nevertheless, the rich interplay between the various forms of transnational public lawsuits continues, as the aftermath of the 1985 murder of Leon Klinghoffer by Palestine Liberation Organization (PLO) terrorists well illustrates. ${ }^{138}$ Klinghoffer's relatives filed a Filartiga-type international tort suit against the PLO in the New York federal district court, a case recently decided on interlocutory appeal. ${ }^{139}$ Shortly thereafter, numerous lobbying groups urged Congress to enact the Anti-Terrorism Act of 1987, which ordered the Attorney General to take necessary legal action to close the various PLO offices in the United States. ${ }^{140}$ The United States reluctantly sued the Palestine Liberation Organization and some of its diplomats in New York federal court, seeking to close its United Nations Observer mission, notwithstanding the 1947 United States-

136. Memorandum for the U.S. as Amicus Curiae submitted in Trajano v. Marcos, No. 86-2448 (9th Cir. 1989). Significantly, the State Department did not sign the Justice Department's Trajano memorandum. Nineteen international law professors and scholars, including three of the original signatories to the Carter Administration's Filartiga memorandum from both the State and Justice Departments, supra note 111, filed a counter-brief reaffirming the correctness of the original U.S. government position. See Cole, Lobel \& Koh, Amicus Curiae Memorandum of International Law Scholars and Practitioners in Trajano v. Marcos, reprinted in 12 HASTINGS INT'L \& COMP. L. REV. 1 (1988). In an unpublished opinion, the Ninth Circuit reversed and remanded the lower courts' dismissal in Trajano and its companion cases for trial, leaving "other issues, notably the difficult question of jurisdiction under 28 U.S.C. $\$ 1350$, to the original consideration of the district courts." Trajano v. Marcos, Nos. 86-2448, 86-15039 (9th Cir. July 10, 1989).

137. At this writing, the only indicator of the Bush Administration's position on transnational public law litigation is its equivocal suggestion-at the request of the Saudi Arabian government-for rehearing en banc in Nelson v. Saudi Arabia, 923 F.2d 1528 (11th Cir. 1991), petition for cert. filed, 60 U.S.L.W. 3294, (U.S. September 26, 1991) (No. 91-522) (finding jurisdiction over Saudi Arabia for a claim by an American citizen of torture committed in Saudi Arabia under the "commercial activity" exception to the Foreign Sovereign Immunities Act). After filing in support of Saudi Arabia, the Administration urged the parties to settle the case. See Lewis, After the War: U.S. Wants Sandi Torture Suit Settled, N.Y. Times, Apr. 23, 1991, AI1, col. 4. Nevertheless, the case may still go to trial. See, e.g., Saudi Case Continues, NaT'L L.J., July 22, 1991, at 6.

138. In October 1985, four terrorists hijacked the cruise ship Achille Lauro, announcing that they were acting "on behalf of" the PLO. During the four-day hijacking, they shot a wheelchair-bound American passenger named Leon Klinghoffer and threw his body overboard. A member of the PLO's Executive Committee apparently admitted during a televised interview that he had "engineered" the Achille Lauro operation. See generally Gooding, Fighting Terrorism in the 1980's: The Interception of the Achille Lauro Hijackers, 12 YALE J. INT'L L. 158, 164-68 (1987).

139. Klinghoffer v. Palestine Liberation Organization, 937 F.2d 44 (2d Cir. 1991), vacating and remanding 739 F. Supp. 854 (S.D.N.Y. 1990). The Klinghoffers charged that the PLO had violated Klinghoffer's rights to be free from assault and battery, false imprisonment, cruel and unusual punishment, torture, terrorism, and summary execution. Although the Second Circuit agreed with the district judge's conclusion that the PLO was not immune from suit and that the complaint raised no political questions, it vacated and remanded for further findings regarding sufficiency of personal jurisdiction and service of process.

140. Pub. L. No. 100-204, 101 Stat. 1406 (codified at 22 U.S.C. $\$ \$ 5201-5203$ (1988)). See generally Koh, The Palestine Liberation Organization Mission Controversy, 82 AM. SOC'Y INT'L PROC. 534, 546-50 (1988). 
United Nations Headquarters Agreement. ${ }^{141}$ Private American citizens and organizations then brought an institutional reform case challenging the Attorney General's action. ${ }^{142}$

At the General Assembly's urging, the Secretary-General invoked the dispute-settlement procedures of that Agreement, which called for final arbitration of any interpretive dispute. When the United States declined to appear, the United Nations sought and won an advisory opinion from the International Court of Justice ruling that the United States had an obligation to arbitrate. ${ }^{143}$ The United Nations then made an extraordinary appearance as amicus curiae before the Southern District of New York, citing the ICJ's advisory opinion, and successfully urging the court to construe the Anti-Terrorism Act consistently with the Headquarters Agreement. ${ }^{144}$ Following its defeat, the Reagan Administration decided not to appeal the case, or to pursue the attempt to close the PLO mission. ${ }^{145}$

The PLO affair displays an array of transnational public law litigants pursuing a range of strategies: an international tort strategy (the Klinghoffers), an institutional reform strategy (the American plaintiffs), and a geopolitical strategy (the United Nations). The incident manifested the characteristic transnational structure of parties and claims, the prospective focus upon norm-enunciation, an attempt to transport norms among domestic and international fora, and an ultimate resolution through institutional dialogue.

The incident's legacy was the strengthening of two legal norms: the domestic canon favoring construction of statutes consistent with international law ${ }^{146}$ and the international norm requiring host states to respect diplomatic privileges granted by treaty. ${ }^{147}$ Both legal principles found deep roots in past internation-

141. Agreement Between the United Nations and the United States of America Regarding the Headquarters of the United Nations, June 26, 1947, 61 Stat. 756, T.I.A.S. No. 1676, 11 U.N.T.S. 11 (1947); see also 22 U.S.C. $\$ 287$ at 132-37 (1988) (implementing Headquarters Agreement as U.S. law).

142. Mendelsohn v. Meese, 690 F. Supp. 1226 (S.D.N.Y.), withdrawn and republished, 695 F. Supp. 1474 (S.D.N.Y. 1988) (raising First Amendment and Bill of Attainder objections to the Anti-Terrorism Act).

143. Applicability of the Obligation to Arbitrate Under Section 21 of the United Nations Headquarters Agreement of 26, June 1947, 1988 I.C.J. 12 (Advisory Opinion of Apr. 26) (holding United States bound to submit dispute precipitated by passage of the Anti-Terrorism Act to binding arbitration).

144. See United States v. Palestine Liberation Organization, 695 F. Supp. 1456 (S.D.N.Y. 1988). The Under Secretary General and Legal Counsel of the United Nations was permitted to address the court at the outset of arguments. See id. at $1458 \mathrm{n}$.**.

145. Pear, U.S. Will Allow PL.O. to Maintain its Office at UN., N.Y. Times, Aug. 30, 1988, at Al, col. 6.

146. See United States v. Palestine Liberation Organization, 695 F. Supp. 1456, 1464-65 (S.D.N.Y. 1988) (citing Murray v. The Schooner Charming Betsy, 6 U.S. (2 Cranch) 64, 118 (1804)). The PLO court read this canon with such force as to make it the international law analog to constitutional law's famous Ashwander principle. Cf. Ashwander v. TVA, 297 U.S. 288, 348 (1936) (Brandeis, J., concurring) (courts have duty to adopt statutory construction that will save statute from constitutional infirmity).

147. Similar issues arose shortly thereafter, when Secretary of State George Shultz refused PLO leader Yasir Arafat a visa to address the United Nations General Assembly, in clear violation of the Headquarters Agreement. See Reisman, The Arafat Visa Affair: Exceeding the Bounds of Host State Discretion, 83 AM. J. INT'L L. 519 (1989). 
al law cases decided by American courts. ${ }^{148}$ But are they quintessentially "horizontal" or "vertical?" The point, of course, is that it is very hard to say.

\section{THE TROubling Vices OF THE "INTERNATIONAL PASSIVE VIRTUES"}

With scarcely a glance back at this rich history, Professor Brilmayer offers a deceptively simple approach to all international law cases in American courts. She urges a "vertical approach" that would apply two easy rules for all international adjudications in U.S. courts. Judges would ask two questions: First, does the case have "vertical elements"? Second, do those vertical elements predominate? The first determination she characterizes as largely nondiscretionary: "[I]f the standing requirement has been met, if the plaintiff has a private right of action and if the treaty is either self-executed or executed by statute, then the case has vertical elements" and "is now properly a case between a state and an individual, as opposed to merely a horizontal case between states." 149 The second determination is prudential, not jurisdictional. If the judge determines that vertical elements "predominate," or form the "center of gravity" of the case (perhaps the same thing), she should adjudicate. But if the case's horizontal elements "completely overshadow the vertical elements," the court should dismiss on political question grounds, because the case is "just 'too political' for an appointed judge to handle." 150

Brilmayer's proposal exhibits the virtue of simplicity and the accompanying vice of oversimplification. She convincingly rebuts misguided "countermajoritarian" objections against international law adjudications in United States courts with arguments that I wholly endorse. ${ }^{151}$ But I cannot embrace her solution of a "vertical" approach to such adjudications. It rests on an unadministrable, manipulable, and ultimately nonexistent distinction between horizontal and vertical cases that bears little resemblance to the Marbury approach whose name she invokes. Most troubling, the distinction ultimately confounds the two laudable objectives that lead her to propose it. It does not necessarily promote the goal of domestic adjudication that she favors: to prevent individuals from abuse of power by the state. Nor does it necessarily promote more thoughtful domestic adjudication of international cases. To the contrary, it offers a poten-

148. See Murray v. The Schooner Charming Betsy, 6 U.S. (2 Cranch) 64, 118 (1804). American courts have long protected rights of diplomats, see, e.g., Respublica v. DeLongchamps, 1 U.S. (1 Dall.) 111 (1784), and have discussed a host state's customary inherent right to exclude aliens, without addressing the rights of diplomats protected by treaty. See, e.g., Chinese Exclusion Case, 130 U.S. 581 (1889).

149. Brilmayer, supra note 12, at 2304 (emphasis added).

150. Id.

151. Professor Brilmayer has performed an important service by rebutting erroneous countermajoritarian claims against domestic application of customary international law made, inter alia, by Trimble, $A$ Revisionist View of Customary International Law, 33 U.C.L.A. L. REV. 665, 675-76 (1986). See Brilmayer, supra note 12 , at 2282-89, 2309-11. 
tially dangerous rule of thumb that judges ignorant of or hostile to international law may invoke to shirk their constitutional duty to say what the law is.

\section{A. Knowing a Vertical Case When You See It}

Professor Brilmayer's crucial assumption is that judges can objectively determine whether issues and cases are horizontal or vertical. Yet this will rarely, if ever, be true. The PLO incident, for example, involved few issues that could be characterized according to Brilmayer's geometry, and many others that simply defy such characterization. Perhaps the rights of the American plaintiffs challenging their own government's right to close the PLO mission and the rights of the PLO diplomats resisting closure could have been called "vertical." But were the rights of the Klinghoffers against the PLO vertical (because the PLO purports to be a state) or horizontal (because the United States has not recognized it as such)? Were the "rights" of the PLO versus the United States "horizontal" (state-to-state) or "vertical" (a nongovernmental organization versus a state)? And what of the rights of the United Nations versus the United States under the Headquarters Agreement? Was that relationship horizontal (treating the United Nations like a state entity), vertical (because the United States belongs to the United Nations), or, as is most likely, a relationship not easily captured by such cookie-cutter terms?

Professor Brilmayer correctly recognizes that "[ $[\mathrm{r}]$ eluctance to apply international law results from forcing international disputes into a horizontal mold, thereby characterizing international disputes in such a way that they appear unsuited for domestic adjudication." 152 Yet the framework that she erects creates countless opportunities for precisely such judicial manipulation. The PLO mission case, for example, raised interpretive issues regarding a statute (the 1987 Anti-Terrorism Act), a treaty (the 1947 Headquarters Agreement), and the construction of the former in light of the latter. The core legal issues were thus the meaning of the statute and the meaning of the treaty. A court applying Brilmayer's framework could have read the treaty interpretation issue as involving only the rights of the contracting parties (the United States and the United Nations), and hence, as a "purely horizontal" question. Since the treaty interpretation question guided the construction of the statute, the court could have concluded that the "center of gravity" of the case was horizontal, and hence unfit for domestic adjudication. Alternatively, the court could have decided that the Headquarters Agreement conferred rights on individual PLO mission members to remain at the United Nations, thus rendering the treaty issue a vertical question. Since the statutory construction issues raised questions of domestic law, the court could then have dubbed the "center of gravity" of the entire case vertical and domestic, and hence, fit for adjudication.

152. Brilmayer, supra note 12 , at 2279 . 
Professor Brilmayer similarly manipulates the decided cases to assert that "the distinction between horizontal and vertical interpretations of international law is already implicit in the case law." 153 She even suggests that her proposed rules of decision for international cases are already de facto in effect. ${ }^{154}$ Yet as the historical review in Part I should make clear, since the Republic began, American courts have applied international law to the cases before them without reference or regard to the distinction Brilmayer now draws. ${ }^{155}$ They have applied international law in cases that plainly satisfy her "horizontal" criteria, ${ }^{156}$ and on occasion, they have refused to apply it in plainly "vertical" cases. ${ }^{157}$ Their reluctance to hear some kinds of international law cases has stemmed from concerns not about these abstract labels, but about comity, separation of powers, and judicial competence. They have decided other cases-particularly the expropriation, human rights, extraterritoriality, and treaty cases Brilmayer discusses-when they have believed those concerns to be alleviated. In short, the horizontal/vertical distinction is not the independent variable that explains the decided case law. To the extent that the distinction mirrors at all the state of the law, it is a crude proxy for a far more complex blend of concerns that have shaped the courts' decisionmaking over time.

Since Sabbatino, American courts have given undue credence to separation of powers and judicial incompetence claims in international law cases. That decision has unfortunately contracted American courts' once-vibrant, historically important role in the development of international law. To suggest, as Professor Brilmayer does, that this state of affairs has somehow resulted from an "invisible hand" application of the horizontal/vertical rule is to celebrate without warrant a defective status quo.

The simple fact is that no meaningful distinction exists between "horizontal" and "vertical" cases, because purely horizontal cases simply do not exist. All international law cases, in Professor Brilmayer's words, "deal[s] not just with 'horizontal' relations between states, but also with the 'vertical' relations between states and people." 158 No case-even those involving the supposedly horizontal issues of recognition, territorial sovereignty, or the international

153. Id.

154. Id at 2280. ("As we look ... at the sorts of cases that have been brought successfully in domestic courts, we will find that these are cases in which the vertical elements predominate over the horizontal ones.").

155. As Brilmayer correctly notes, they have also done so with little heed to the overblown "countermajoritarian" claims of revisionist critics of customary international law, like Professor Trimble. See supra note 151 .

156. See, e.g., cases described supra notes 41-46.

157. The most prominent example is, of course, Banco Nacional de Cuba v. Sabbatino, 376 U.S. 398 (1964), an expropriation case. See supra text accompanying note 86.

158. Brilmayer, supra note 12 , at 2295 . The point recalls the Supreme Court's reason for replacing the formalistic in personam, in rem, and quasi in rem categories of personal jurisdiction with a flexible "minimum contacts" standard: “"All proceedings, like all rights, are really against persons." Shaffer v. Heitner, 433 U.S. 186, 207 n.22 (1977) (citation omitted). 
legality of hostilities-is purely or even predominantly "horizontal," in the sense of raising only the "rights" of states.

Each of these supposedly horizontal situations has important vertical impacts. When one country recognizes another, it does not merely bestow rights horizontally on the other state, it also grants rights vertically to individuals holding property pursuant to arrangements with the newly recognized state. ${ }^{159}$ When a court holds a war unlawful, it does not merely recognize the horizontal legal right of the other state to resist the use of force, it also vertically recognizes the rights of the individuals warred upon (or whose property has been seized) to be free of the unlawful war. ${ }^{160}$ When a court recognizes territory as belonging to one state, it effectively bestows rights on the individual owners of the contested territory within the lawfully owning state and divests rights from their counterparts in the other. ${ }^{161}$ As Brilmayer concedes, the "vertical" approach is not an alternative to, but "really an expansion of the horizontal model, for it recognizes that vertical as well as horizontal relations are important."162 Thus, the real dichotomy is not between "horizontal" and "vertical" cases, but between simplistic and realistic characterizations of the legal issues raised by the same case.

By proposing the horizontal/vertical distinction as a new rule of decision, Professor Brilmayer ignores the central lesson of Nuremburg: that individuals have both rights and responsibilities under international law, and that those rights and responsibilities are appropriate subjects of adjudication. For example, Brilmayer argues that an individual may not sue to challenge the legality of a war of aggression, because such a claim is horizontal-the "individual is really asserting the rights of the state which is suffering illegal aggression."163 But if Nuremburg resolved anything, it is that the crimes "for which there shall be individual responsibility" include crimes against peace, "namely, planning, preparation, initiation or waging of a war of aggression," no less than war crimes and crimes against humanity. ${ }^{164}$ Thus, Iraq's recent illegal aggression

159. Cf. United States v. Pink, 315 U.S. 203 (1942); United States v. Belmont, 301 U.S. 324 (1937); M. Salimoff \& Co. v. Standard Oil Co., 262 N.Y. 220, 186 N.E. 679 (1933).

160. $C f$. Brown v. United States, 12 U.S. (8 Cranch) 110 (1814) (invalidating executive seizure of British property before War of 1812).

161. Cf. Kansas v. Colorado, 206 U.S. 46, 97-99 (1907) (applying international law to settle boundary dispute and acknowledging potential impact of decision on private rights).

162. Brilmayer, supra note 12, at 2295 ("The new emphasis on vertical relations between states and people does not deny the relevance of horizontal relations between states. While the horizontal model seemed to attempt to exclude non-state actors, the vertical model does not, correspondingly, exclude all horizontal state/state relations from international law.").

163. Id. at 2300; see also id. (suit by an individual of an invaded state alleging the illegality of the invasion is "a horizontal claim, since the basis for the cause of action is the inter-state norms prohibiting aggression").

164. Charter of the International Military Tribunal at Nuremburg, Art. 6, Agreement for the Prosecution and Punishment of the Major War Criminals of the European Axis, Aug. 8, 1945, 59 Stat. 1544, 1547, 82 U.N.T.S. 279, 288. See also I. BROWNLIE, PRINCIPLES OF PUblic INTERNATIONAL LAw 562 (3d ed. 1979) ("[C]rimes against peace were defined authoritatively and prosecuted for the first time at Nuremburg. But whatever the state of the law in 1945, Article 6 of the Nuremberg Charter has since come to represent 
against Kuwait both invaded the rights of individual Kuwaitis and engaged the individual responsibility of Saddam Hussein. To suggest that aggression raises only horizontal, state-to-state issues is to reject the Nuremburg understanding by exalting states' rights over individual rights and resurrecting state sovereignty as a barrier to adjudication. ${ }^{165}$

What makes Brilmayer's suggestion most curious are her concession that historically, American courts regularly "dealt with questions of the existence and consequences of a state of war" and her recognition (in other work) that the "My Lai and Nuremburg trials suggest that judicial investigations even into wartime activities are possible." 166 The inconsistency ultimately stems from a fundamental contradiction within her position. Although in one breath she rejects the dualist tradition in international law, which artificially separates legal relations among states from legal relations among states and individuals, in the next breath she perpetuates that tradition by enshrining the horizontal/vertical distinction as her operative rule of decision for American courts. As Part I suggests, American courts have decided international law cases without reference to the dualist tradition from the early days of the Republic, and more recently since Nuremburg and the explosion of transnational commercial litigation. It makes little sense now to embed into law a theoretical distinction that both history and commonsense have so firmly rejected.

\section{B. The False Precision of Legal Geometry}

As the PLO example illustrates, one could play endless games challenging the administrability and manipulability of Brilmayer's two-part test. ${ }^{167}$ One need not be a visionary or a cynic to see that all of these issues would soon arise and multiply if courts were to adopt the vertical approach. Transnational

general international law.").

165. The International Law Commission is currently considering a proposal for an international criminal court in which cases charging crimes against peace could be submitted, inter alia, by individuals. See McCaffrey, supra note 70 , at 932 .

166. Brilmayer, supra note 12 , at 2300 n.113; L. BRILMAYER, supra note 13, at 92 . Brilmayer's distinction collapses when she concedes that there is "a vertical way of explaining norms prohibiting state aggression", but insists that "while many norms could in theory be explained in either horizontal or vertical terms, in practice they are best described by one or the other." Brilmayer, sıpra note 12, at 2301 n. 114.

167. What, for example, constitutes a vertical "element"-the participation of an individual party, a case's likely impact on individuals, or the existence of legal rules or issues peculiarly couched in terms of state power over individuals? Does impact on multinational corporations, nongovernmental organizations, unrecognized states, international organizations, and other nonstate actors count as impact on "individuals"? Should the official acts of a head of state (e.g., Saddam Hussein) be deemed acts of a state or of an individual? How should a judge count and compare these vertical elements? And perhaps most important, how should one determine that vertical elements "predominate" or form the "center of gravity" of the case? Can one potentially dispositive "vertical" issue predominate over, say, five peripheral horizontal ones? Can a judge realistically make such an assessment at the outset of a case, before considering the merits? And what should the judge do in a standard transnational public law case, which combines complex parties and multiple issues of state, federal, and international law-both treaty and customary international law-as well as canons of domestic statutory construction that require judicial reference to international norms? See, e.g., Sanchez-Espinoza v. Reagan, 770 F.2d 202 (D.C. Cir. 1985) (raising multiple issues). 
litigants would strategically adjust their pleadings or choose their plaintiff groups so as to shoehorn their suits into judicially ratified litigation structures. The more rigidly judges applied the horizontal/vertical rule, the more quickly these cases would become formalistic exercises in artful pleading. The more flexibly judges applied the rule, the more likely the very result that Brilmayer disapproves: namely, "a standardless [judicial] power to 'duck issues' that are politically troublesome." 168 Labeling would overcome analysis-as has arguably occurred with the "rational basis/strict scrutiny" approach to modern equal protection doctrine and the mechanistic due process analysis of Board of Regents $v$. Roth $h^{169}$-as judges worked backward from their desired political outcomes to the doctrinally prerequisite "horizontal" or "vertical" label.

But let us assume for the moment that all such problems could be worked out through reasoned elaboration and judicious doctrinal development. The deeper question is whether any of us, including Professor Brilmayer, would be happy with the doctrine that ultimately emerged. The answer, I fear, is no, because Brilmayer's doctrinal recommendation does not further her jurisprudential goals. Her two-part test promotes neither the use of domestic adjudication to prevent individuals from abuse of state power nor more thoughtful domestic adjudication of international cases.

To see why, we must walk through a typical transnational public lawsuit using Brilmayer's analysis. Take the controversial case of Tel-Oren v. Libyan Arab Republic, ${ }^{170}$ in which three different judges of the D.C. Circuit agreed, albeit on differing rationales, to dismiss an Alien Tort Statute suit by Israeli citizens who had been subjected to PLO torture and terrorism in Israel. By Brilmayer's own lights, the case seems clearly "vertical"-it was a human rights case in which plaintiffs were asserting their own liberty interests to be free from torture, not any right of Israel's. Yet under Brilmayer's test, the judge would ask first whether the plaintiffs have standing, a cause of action, and whether the treaties they invoke are self-executing. If the answer to all three questions were yes, "then the case has vertical elements," and the judge could proceed to the next inquiry. ${ }^{171}$ If any question could be answered no, the judge would be obliged to dismiss. Proceeding much as Brilmayer proposes, Judge Bork concluded in Tel-Oren that the case should be dismissed both because plaintiffs lacked a cause of action and because the treaties they had invoked were nonself-executing. ${ }^{172}$

Even supposing plaintiffs could surmount the first barrier, the court would then have to ask Brilmayer's second, discretionary question: whether the

168. Brilmayer, supra note 12 , at 2301 n.115.

169. 408 U.S. 564 (1972) (creating entitlement trigger for due process analysis). See generally Diver, The Wrath of Roth, 94 YALE L.J. 1529 (1985).

170. 726 F.2d 774 (D.C. Cir. 1984), cert. denied, 470 U.S. 1003 (1985).

171. Brilmayer, supra note 12, at 2304. ring).

172. Bork did not challenge the plaintiffs' standing. See Tel-Oren, 726 F.2d at 799 (Bork, J., concur- 
vertical elements in the case are strongly outweighed by the horizontal ones. ${ }^{173}$ This determination, she claims, approximates the question whether the case has such large political ramifications that it would be inappropriate for judicial resolution. At the outset, all of the issues in Tel-Oren were arguably vertical: individual Israelis were suing the PLO, which under international law is not a state. ${ }^{174}$ Now suppose that as part of a delicate political bargain, the United States recognized the PLO as a state, the new state of Palestine ratified all past acts of its members, and the United States then filed a brief with the Tel-Oren court urging dismissal of the suit to protect sensitive and evolving "interstate" political negotiations with Palestine. Under Brilmayer's analysis, these political moves would provide a skeptical judge with a discretionary basis for dismissal. He could easily decide that the horizontal issues between the states now "dominated" the vertical issues between the victims and the PLO, and dismiss on political question grounds.

Yet ironically, the U.S. government's act of recognition would have made it even clearer that the Israeli victims had been unlawfully subjected to the sovereign power of the Palestine state. ${ }^{175}$ Although the case would have become more political, it would now more clearly involve the human rights of the victims to be free from official torture and state terrorism. Brilmayer's instinct is that in such a newly vertical situation, a court should play its traditional role of protecting individual rights. But her doctrinal recommendation would give the judge far greater discretion than before to avoid the case on "horizontal," political question grounds.

If one were to ask the judge for his real reasons for dismissing on political question grounds, he would probably not reply, "because horizontal issues are the center of gravity of the case." His more likely reasons would be respect for the new Palestinian state, deference to the executive branch, and concerns about his competence to deal with the issues: in short, comity, separation of powers, and judicial incompetence. But if these are the real reasons driving judicial decision, why hide them behind the labels "horizontal" and "vertical"? If courts are allowed to cloak their true grounds for decision behind the false precision of geometry, the dispositive issues will be obscured. Over time, the labels will hinder, not help, the courts in evolving a principled conception of a lawful society, governed by norms of international as well as domestic law.

In short, Brilmayer's approach is misguided. It is not the "vertical" elements of a case, but its legal elements-those issues upon which there is domestic

173. Brilmayer, supra note 12 , at 2300 .

174. No state had taken a position in the suit except for Libya, which had been dismissed on foreign sovereign immunity grounds. See Tel-Oren, 726 F.2d at 775-76 n.l (Edwards, J., concurring).

175. Indeed, in Tel-Oren itself, Judge Edwards-the judge most sympathetic to plaintiffs' claims-voted to dismiss because the case was insufficiently vertical. Judge Edwards reasoned that torture conducted by a nonstate actor such as the PLO did not constitute an offense against the law of nations, and thus, that the case lacked the "state action" necessary to trigger the court's jurisdiction under the Alien Tort Statute. Id. at 788, 791-96 (Edwards, J., concurring). 
or international law for courts to apply-that render the case appropriate for domestic adjudication. Brilmayer's international passive virtues, like their domestic counterpart, exhibit not-so-subtle vices. They offer individuals less judicial protection against the power of the state and offer United States judges a tempting, mechanistic rationale for dropping from their dockets important transnational public law cases that they can and should adjudicate.

\section{A Better Approach: Doctrinal Targeting}

The better way to decide these cases is to confront openly the three concerns-comity, separation of powers, and judicial incompetence-that actually trouble the courts. Rather than applying overbroad rules that treat all transnational public law cases as inherently unfit for domestic adjudication, courts should target their concerns by applying those doctrines that have been specifically tailored to address them.

Tel-Oren provides two examples of overbroad rules that would lead to jurisdictional overkill in international law cases. Concerned about separation of powers, Judge Bork concluded that the plaintiffs lacked a cause of action, because the treaties upon which they relied were nonself-executing; because customary international law "conferred" no cause of action upon them; and because judicial implication of a private right of action would usurp the role of the political branches. ${ }^{176}$ Concerned about judicial competence, Judge Robb seized instead upon the political question doctrine. He argued that Tel-Oren should be dismissed because of "the inherent inability of federal courts to deal with cases such as this one.... [T] he pragmatic problems associated with [the case] are numerous and intractable," the international legal issues "defy judicial application," and the facts were "not susceptible to judicial handling." 177 Concerned about comity, the pre-Sabbatino Act of State cases offer a third example of an overbroad rule. To respect foreign sovereignty, these cases suggest, suits that raise challenges to public acts of sovereigns taken within their own territory should automatically be dismissed. ${ }^{178}$

Each of these approaches voices a valid concern, but addresses it with an overcompensating blanket rule. ${ }^{179}$ Each fails to recognize that the severity of its prime concern will vary in different transnational cases, depending in part on whether the suit is an international tort or an institutional reform case. In my view, federal courts could better address their varied concerns on a case-bycase basis, by selectively applying existing doctrines of federal jurisdiction, civil

176. Id. at $801-08$ (Bork, J., concurring).

177. Id. at 823, 826 (Robb, J., concurring).

178. See cases discussed supra note 60 .

179. Brilmayer also draws such a blanket, nondiscretionary line for dismissal. See supra text accompanying note 149. 
procedure, and foreign sovereignty law to target separation-of-powers, judicial competence, and comity concerns as they legitimately arise.

\section{Separation-of-Powers Concerns}

The doctrinal-targeting approach is best illustrated with respect to separation-of-powers issues. Transnational public lawsuits trigger three kinds of separation-of-powers concerns, which judges should address in turn: those raised by the existence of the claim, those raised by the nature of the claim, and those raised by the identity of the defendant. ${ }^{180}$ Consider first Judge Bork's "no private right of action" approach in Tel-Oren, which bears some resemblance to Professor Brilmayer's threshold standing inquiry. Upon examination, Bork's three inquiries collapse into one, all of which concern the existence of plaintiff's claim. Properly understood, the questions whether the treaties upon which plaintiff relies are self-executing; whether the plaintiff has a cause of action under customary international law; and whether the plaintiff has an "implied" private right of action all reduce to this: whether the plaintiff has stated a claim upon which judicial relief can be granted. ${ }^{81}$

As Professor McDougal pointed out more than thirty years ago, little insight is gained from labeling a treaty as "self-executing" or not. ${ }^{182}$ A better approach would be simply to dispense with the self-executing terminology, asking instead whether the plaintiff has an enforceable claim. If Congress has enacted an implementing statute that expressly authorizes a plaintiff to enforce the treaty, the plaintiff's claim would derive from the statute, not the treaty. If that statute contains no express cause of action, the court should simply apply the

180. I see no separation-of-power problems raised by the plaintiff's identity as a foreign state, although that fact may cause other difficulties. The foreign state might, for example, lack the constitutional or statutory rights necessary to support its claim. See, e.g., Damrosch, Foreign States and the Constitution, 73 VA. L. REV. 483, 490-94, 498-99 (1987); Pfizer, Inc. v. Government of India, 434 U.S. 308 (1978) (rejecting claim that foreign government is not a "person" entitled to sue for treble damages under the Clayton Act). In addition, a court could conclude that a foreign government cannot validly sue as parens patriae on behalf of its citizens, as India has done, for example, in the Bhopal case. See supra notes 125-26.

181. On a motion to dismiss for failure to state such a claim under FED. R. CIV. P. 12(b)(6), the facts should, of course, be construed in the light most favorable to the plaintiff. See, e.g., Rosen v. Texas Co., 161 F. Supp. 55, 57 (S.D.N.Y. 1958) ("a complaint will not be dismissed for failure to state a claim on which relief can be granted "unless it appears to a certainty that plaintiff is entitled to no relief under any state of facts which could be proved in support of the claim" ") (citation omitted). Brilmayer suggests a fourth barrier, standing, but as several commentators have noted, the standing requirement ultimately reduces to a requirement that the plaintiff have a claim. See, e.g., Amar, Law Story (book review), 102 HARV. L. REV. 688, 718 n.154 (1989); Fletcher, The Structure of Standing, 98 YALE L.J. 221, 223-24 (1988).

182. When the precise issue before a decision-maker is whether some further legislative act is required, it obviously assists the resolution of the issue but little to proclaim that if the agreement is self-executing no further action is required, but that if it is non-self-executing, further action is required. The words self-executing and non-self-executing embrace neither intrinsic or historic meaning nor magic to resolve the issue.

McDougal, The Impact of International Law upon National Law: A Policy-Oriented Perspective, 4 S.D.L. REV. 25, 77 (1959). 
familiar Cort v. Ash doctrine for implied statutory right of actions to decide whether plaintiff has a cognizable claim for relief. ${ }^{183}$ Application of the Cort doctrine-which raises principally questions of legislative intent-would target and thereby allay any lingering separation-of-powers concerns. ${ }^{184}$

If no implementing statute exists, the court should ask whether the plaintiff may enforce the treaty directly. To answer that question, the court should closely examine the text and context of the treaty to decide whether the plaintiff is a member of a class that the treaty intended to protect or upon whom the treaty bestows rights. ${ }^{185}$ If so, the court should apply Chief Justice Marshall's rebuttable presumption from Foster \& Elam v. Neilson that the treaty gives rise to an individual claim of relief. ${ }^{186}$ The court may find this presumption of private enforcement rebutted if the treaty's history, negotiations, and the practical construction adopted by the parties clearly evince no intent to allow plaintiffs to invoke the treaty in domestic courts. ${ }^{187}$ But once again, no separation-of-powers problem would arise because the court would be conducting straightforward treaty interpretation. ${ }^{188}$

183. See Cort v. Ash, 422 U.S. 66, 78 (1975) (asking whether plaintiff is one of class for whose special benefit statute was passed; whether legislature intended to create or deny private remedy; whether private remedy is consistent with legislative scheme; and whether cause of action is one traditionally relegated to state law). See also J.I. Case Co. v. Borak, 377 U.S. 426 (1964); Cannon v. University of Chicago, 441 U.S. 677 (1979); Merrill, Lynch, Pierce, Fenner \& Smith, Inc. v. Curran, 456 U.S. 353 (1982); Thompson v. Thompson, 484 U.S. 174 (1988).

184. See, e.g., Merrill, Lynch, 456 U.S. at 376 (Stevens, J.) ("Courts . . are organs with historic antecedents which bring with them well-defined powers. They do not require explicit statutory authorization for familiar remedies to enforce statutory obligations.') (citation omitted).

185. For a similar test, see Riesenfeld, The Doctrine of Self-Executing Treaties and U.S. v. Postal: Win at any Price?, 74 AM. J. INT'L L. 892 (1980):

A treaty provision which by its terms and purpose is meant to stipulate the immediate and not merely progressive creation of rights, privileges, duties, and immunities cognizable in domestic courts and is capable of being applied by the courts without further concretization is self-executing by virtue of the constitutional mandate of Article VI of the Constitution.

Id. at 900-01 (emphasis in original). The Court has de facto applied a similar analysis in enforcing Friendship, Commerce and Navigation treaties at the request of individuals. See, e.g., Asakura v. City of Seattle, 265 U.S. 332 (1924). In thinking through this issue, I have benefited from Floyd G. Short's excellent unpublished paper, Implied Rights of Action Under Treaties of the United States (1990) (on file with the author).

186. See supra text accompanying notes 79-83.

187. For a recent example of this interpietive method, see Eastern Airlines Inc. v. Floyd, $111 \mathrm{~S}$. Ct. 1489 (1991). In determining the treaty's domestic effect, the key issue should not be the intent of the negotiators but the intent of the Senate when it consented to ratification of all or part of what the negotiators agreed to. Koh, The President Versus the Senate in Treaty Interpretation: What's All the Fuss About?, 15 YALE J. INT'L L. 331,339 (1990). Moreover, the court may, under certain circumstances, look to the negotiating history of the treaty, executive branch representations during the advice and consent process, and other preratification materials that were before the Senate when it gave its consent. See id. at 338-44; see also United States v. Stuart, 489 U.S. 353, 367 n.7 (1989).

188. See, e.g., Japan Whaling Ass'n v. American Cetacean Soc'y, 478 U.S. 221, 230 (1986) ("The courts have the authority to construe treaties and executive agreeements."); Jones v. Meehan, 175 U.S. 1, 32 (1899) ("The construction of treaties is the peculiar province of the judiciary . . . .). In construing treaties, United States courts have tended to give great, but not conclusive, weight to interpretations offered by the Executive Branch. See, e.g., Sumitomo Shoji Am., Inc. v. Avagliano, 457 U.S. 176, 184-85 (1982); RESTATEMENT (THIRD), supra note 9, at $\$ 326(2)$. 
Nor do separation-of-powers difficulties arise when a plaintiff alleges a claim for relief arising directly from customary international law. As Professor Brilmayer notes, it would be anachronistically positivistic to ask-as Judge Bork did in Tel-Oren - whether customary international law "confers" a private "cause of action" on the plaintiff. ${ }^{189}$ As Part I demonstrates, individuals were asserting claims for relief based directly upon the law merchant and the law maritime centuries before the concept of a "cause of action" came into being. ${ }^{190}$

Instead the court should ask whether federal common law already recognizes plaintiff's claim. For example, Filartiga and its progeny have now firmly recognized a federal common law remedy against official torture under the Alien Tort Statute. ${ }^{191}$ That holding did not trench upon separation of powers, for by enacting the Alien Tort Statute, Congress authorized the federal courts to fashion a federal common law of public tort remedies for international crimes. Far from being unbounded, the courts' discretion to recognize such federal common law claims is guided both by the scope of the statutory terms ${ }^{192}$ and by the range of customary international law violations about which there is universal consensus. ${ }^{193}$ Thus, even if an American citizen asserted a torture claim against a nondiverse American official, his claim would "arise under" federal common law for purposes of the federal question jurisdiction provision. ${ }^{194}$

If no court has yet recognized the plaintiff's claim under federal common law, the judge should literally "find" customary international law-as federal courts have done over the centuries-to determine whether a clear international consensus has crystallized around a legal norm that protects or bestows rights

189. Brilmayer, supra note 12, at 38; see also D'Amato, supra note 134; Tel-Oren v. Libyan Arab Republic, 726 F.2d 774, 779 (D.C. Cir. 1984) (Edwards, J., concurring), cert. denied, 470 U.S. 1003 (1985) (Bork's view ignores that law of nations has always relied upon domestic remedies).

190. See Davis v. Passman, 442 U.S. 228, 237-38 (1978) (tracing "cause of action" to New York Code of Procedure of 1848 and concluding that it "refer[s] roughly to the alleged invasion of "recognized legal rights' upon which a litigant bases his claim for relief') (citation omitted).

191. See supra note 118. See also Forti v. Suarez-Mason, 672 F. Supp. 1531 (N.D. Cal, 1987), modified, 694 F. Supp. 707 (N.D. Cal. 1988) (recognizing similar remedies for prolonged arbitrary detention, summary execution, and disappearance).

192. U.S. CoNST. art. I, $\$ 8$, cl. 10 grants Congress the power "to define and punish ... Offences against the Law of Nations." In the Alien Tort Statute, Congress in turn granted the federal courts jurisdiction to hear "torts" in violation either of "the law of nations" (construed in Filartiga to mean evolving customary international law) or "treaties of the United States."

193. At a minimum, the list would include the jus cogens norms, which are so universally accepted that they are considered obligatory upon nations even in the face of an inconsistent treaty. See, e.g., RESTATEMENT (THIRD), supra note $9, \S 404$ (defining universal crimes as piracy, slave trade, attacks on or hijacking of aircraft, genocide, war crimes, and perhaps certain acts of terrorism); see also id. $\$ 702$ (state violates international law if, as matter of state policy, it practices, encourages, or condones official genocide, slave trade, murder, torture, prolonged arbitrary detention, or systematic racial discrimination).

194. 28 U.S.C. $\$ 1331$ (1988); see also Illinois v. City of Milwaukee, 406 U.S. 91, 100 (1972) ("§ 1331 jurisdiction will support claims founded upon federal common law as well as those of a statutory origin"). 
upon a group of individuals that includes plaintiffs. ${ }^{195}$ If so, the court could use its federal common lawmaking authority under the Alien Tort Statute to make violation of that norm a federal "tort in violation of the law of nations" for purposes of the Statute. ${ }^{196}$ Even in cases not involving the Alien Tort Statute, the court could still find and follow customary international law without raising separation-of-powers concerns. In W. S. Kirkpatrick Co. v. Environmental Tectonics Corp. ${ }^{197}$ a unanimous Supreme Court made clear that the Act of State Doctrine declares not just an abstention doctrine, but a rule of decision. ${ }^{198}$ By so saying, the Court acknowledged that federal courts not only have common law power to flesh out the authority delegated them by statute, but also constitutional authority to prescribe rules of substance and procedure within the unique "enclave of federal judge-made law" regarding international relations. ${ }^{199}$

Having settled that a transnational claim exists, the court should next inquire into its nature: specifically, whether it is inherently too political for a court to decide. At this stage, judges should not invoke the political question doctrine indiscriminately to allay undifferentiated separation-of-powers concerns. Unlike some, I believe that there is a political question doctrine, which asks whether the Constitution has textually committed to another governmental branch the power to make the determination now requested from a court. ${ }^{200}$ Yet all of the questions examined thus far are quintessential questions of legal interpretation. Interpretation of statutes and treaties are peculiarly the province of courts. ${ }^{201}$ Similarly, as Sabbatino suggested, "the greater the degree of codifi-

195. Cf. Henkin, supra note 23 , at 1561-62 ("In a real sense federal courts find international law rather than make it, ... as is clearly not true when federal judges make federal common law pursuant to constitutional or legislative delegation.") (emphasis in original). This technique (which the Second Circuit applied in Filartiga) parallels my proposal for dealing with treaties, for it asks whether de facto international agreement has emerged condemning a particular legal violation.

196. Cf. supra note 118 .

197. 110 S. Ct. 701 (1990); see supra note 106.

198. $110 \mathrm{~S}$. Ct. at 705 ("The act of state doctrine is not some vague doctrine of abstention but a 'principle of decision binding on federal and state courts alike."') (emphasis in original) (citation omitted). Similarly (and ironically), the former Judge Bork recently urged, as an advocate, that the Court adopt a federal common law rule of decision to protect multinational banks against offshore liabilities incurred by their foreign branches. See Citibank, N.A. v. Wells Fargo Asia Ltd., 110 S. Ct. 2034, 2041-42 (1990).

199. Banco Nacional de Cuba v. Sabbatino, 376 U.S. 398, 426 (1964); see also Texas Indus., Inc. v. Radcliff Materials, Inc., 451 U.S. 630, 641 (1981) ("absent some congressional authorization ... , federal common law exists only in such narrow areas as ... international disputes implicating . . our relations with foreign nations ... because the ... international nature of the controversy makes it inappropriate for state law to control"). Although customary international law rules are not made exclusively by our elected officials, a court can embody them in federal common law rules that can, in turn, be overruled by legislation, thereby mitigating any countermajoritarian concerns.

200. If so, the court would not "abstain," but rather, interpret the Constitution and find the political branch's determination to be conclusive. Compare $\mathrm{H}$. KOH, supra note 1, at 218-24 with Henkin, Is There a 'Political Question' Doctrine?, 85 YALE L.J. 597 (1976).

201. See Japan Whaling Ass'n v. American Cetacean Soc'y, 478 U.S. 221, 230 (1986) ('Under the Constitution, one of the Judiciary's characteristic roles is to interpret statutes, and we cannot shirk responsibility merely because our decision may have significant political overtones."); Jones v. Meehan, 175 U.S. 1,32 (1899) ("The construction of treaties is the peculiar province of the judiciary . . . "). 
cation or consensus concerning a particular area of international law, the more appropriate it is for the judiciary to render decisions regarding" customary rules in those areas. ${ }^{202}$ Thus, the political question doctrine should rarely be invoked in transnational public lawsuits, except in those cases where there is so little consensus about the international rules at issue that there is literally no law for the court to apply. Inevitably, of course, international law cases will be politically charged. But as Baker v. Carr reminds us, the doctrine is "one of 'political questions,' not one of 'political cases,' " and political heat alone does not a separation-of-powers violation make. ${ }^{203}$

Once the court concludes that the plaintiff has stated a claim, and that the claim is justiciable, it should look to the identity of the defendant. At this stage, judges should recognize that the intensity of the separation-of-powers concerns raised by a public transnational case will vary dramatically, depending upon whether the defendants are aliens acting under color of state law, foreign heads of state, foreign governments, or the United State government and its officials. But even as one moves along this spectrum, the number of doctrines of federal jurisdiction currently available to address these concerns on a discretionary, case-by-case basis will multiply.

In Filartiga, for example, where an alien sued another alien acting under color of state authority for an international crime, adjudication did not interfere with the executive branch's conduct of foreign affairs. The executive branch urged adjudication of the suit. ${ }^{204}$ More important, an international crime, by definition, is an act that has been condemned not only by the United States, but also by the governments of all civilized nations (which in Filartiga included the country in whose territory and by whose national the crime was committed). Thus, federal courts can render rulings in such cases without necessarily touching upon national nerves or embarrassing the executive branch in the conduct of its political functions. ${ }^{205}$

In the second class of cases, where an alien sues a foreign head of state or government directly for an international crime, separation-of-powers concerns heighten, for the executive branch, not the judiciary, bears constitutional responsibility for recognizing and conducting diplomatic relations with foreign states and governments. Yet in these cases, federal courts may likewise assuage their concerns by applying existing doctrines that were designed specifically to meet them. Where the executive branch suggests immunity, and the foreign government does not waive it, suits against heads of states can be dismissed

202. 376 U.S. at 428.

203. Baker v. Carr, 369 U.S. 186, 217 (1962).

204. See supra text accompanying note 111 .

205. Sabbatino, 376 U.S. at 428; see also U.S. Filartiga Memorandum, supra note 111, at 605 ("The compatibility of international law and Paraguayan law [condemning official torture] significantly reduces the likelihood that court enforcement would cause undesirable international consequences and is therefore an additional reason to permit private enforcement."). 
on grounds of head-of-state or diplomatic immunity. ${ }^{206}$ After Amerada Hess, suits against foreign states must be brought under the Foreign Sovereign Immunities Act, and may be dismissed on grounds of foreign sovereign immunity if no exception applies. ${ }^{207}$ Even if the defendant is not immune, the Act of State doctrine may nevertheless require dismissal of particular issues or the entire lawsuit. Over time, each of these doctrines has been tailored by either Congress or the courts with the express goal of alleviating separation-of-powers concerns.

Finally, when an alien sues the United States government and its officials for their alleged violations of international law, separation-of-powers concerns become most serious. They are particularly troubling in institutional reform cases, where the adjudication or the relief could interfere in the ongoing operation of American foreign policy. Yet here too, courts possess ample doctrinal tools to target these concerns on a case-by-case basis. They may apply the law of domestic sovereign immunity and the Federal Tort Claims Act to protect the United States government on a case-by-case basis. ${ }^{208}$ The courts may apply the law of official immunities developed in the Bivens and Section 1983 context to protect individual officials from unwarranted transnational suits as they arise. ${ }^{209}$ To note that these separation-of-powers doctrines exist is not to suggest that all, or even most, of the cases that comprise them were correctly decided. The point is that suits that potentially raise separation-of-powers concerns should not be unthinkingly dismissed at the threshold stage, when courts have ample techniques available to answer those concerns as they arise.

\section{Judicial Competence Concerns}

Courts can use much the same case-by-case strategy to address judicial competence concerns, without relying upon a blanket political question approach of the kind urged by Judge Robb in Tel-Oren. ${ }^{210} \mathrm{~A}$ federal court's competence to decide a particular transnational public suit will turn critically upon both the particular facts and law relevant to the decision. In some cases, factfinding will be easy, because a defendant will claim responsibility or

206. See generally Note, Ex-Head of State Immunity: A Proposed Statutory Tool of Foreign Policy, 97 YALE L.J. 299, 301 n.10 (1987) (collecting cases).

207. See supra note 133 .

208. See generally P. SCHUCK, supra note 101, at 35-41, 113-18 (describing these doctrines).

209. See, e.g., Harlow v. Fitzgerald, 447 U.S. 800 (1982) (immunity of executive officials); Nixon v. Fitzgerald, 457 U.S. 731 (1982) (presidential immunity). See generally Kinports, Qualified Immunity in Section 1983 Cases: The Unanswered Questions, 23 GA. L. REv. 597 (1989).

210. See supra text accompanying note 177 . The foregoing analysis suggests that the political question doctrine is, in any event, an inappropriate vehicle for addressing a court's pragmatic concerns about its ability to conduct fact and law-finding. The doctrine's constitutional core more appropriately addresses separation of powers, and the court's alleged usurpation of a coordinate branch's constitutionally assigned role. 
because dispositive facts will be matters of public record. ${ }^{211}$ In other cases, the fact-finding will be complex, but not more than in any transnational case, where international judicial assistance and federal rules can aid the court in supervising discovery. ${ }^{212}$ When difficult questions of international law do arise, American courts have traditionally been deemed competent to decide them. Particularly when statutory and treaty interpretation issues arise, courts are not merely qualified, but constitutionally obliged to adjudicate.

Nor are questions of customary international law, which courts routinely resolved in the eighteenth and nineteenth centuries, beyond judicial ken. The rules of customary international law are far more accessible to domestic courts today than they were decades ago. ${ }^{213}$ Interpretation of what Professor Brilmayer calls "horizontal" rules pose no special competence problems. Take, for example, the three she specifically mentions: recognition, territorial sovereignty, and the international legality of hostilities. In our constitutional system, the power to recognize a foreign state or government is textually assigned to the political branches, but the customary international law rules of recognition are clear and capable of judicial application in appropriate cases. ${ }^{214}$ Similarly, the vast majority of the cases within the original jurisdiction of the Supreme Court over the past two centuries have involved territorial disputes between states, undercutting any claim that such disputes defy judicial resolution. ${ }^{215}$ Finally, as American courts regularly showed before Vietnam and the World Court demonstrated in the Nicaragua case, courts can and do make determinations regarding the international legality of hostilities, notwithstanding persistent claims that such questions are inherently political. ${ }^{216}$ In short, the case simply

211. See, e.g., Tel-Oren v. Libyan Arab Republic, 726 F.2d 774, 799 (D.C. Cir. 1984) (Bork, J., concurring), cert. denied, 470 U.S. 1003 (1985) (PLO "claimed responsibility" for attack and Libya gave terrorists a "'hero's welcome").

212. See generally G. BORN \& D. WESTIN, INTERNATIONAL CIVIL LITIGATION IN UNITED STATES COURTS 262-335 (1989) (enumerating available methods of extraterritorial discovery, including letters rogatory, Hague Evidence Convention, and direct discovery under Federal Rules of Civil Procedure). I do not deny that there might be cases in which factfinding proves not just difficult, but impossible-for example, if classified foreign government documents constituted the critical evidence-but such cases have been few and far between in the transnational commercial setting.

213. See supra note 107. Perhaps the greatest irony of Tel-Oren was that, even as Judge Robb bemoaned the incompetence of federal judges to determine international legal issues, 726 F.2d at 823 (Robb, J., concurring), the other two judges disproved his claim by engaging in extended, detailed analyses of just such questions. See id. at 775 (Edwards, J., concurring): id. at 798 (Bork, J., concurring). Similarly, FED. R. CIV. P. 44.1 provides methods whereby even complex issues of foreign law may be determined to the satisfaction of the court.

214. See RESTATEMENT (THIRD), supra note 9, at 80 ("While the grant or denial of formal recognition is a political act within the discretion of government (and usually of their executive branches), whether an entity ... is entitled to be treated as a state is an objective question [that] might be subject to judicial determination by international or national tribunals."); see also id. at $\$ \S 202-203$ (stating international rules of recognition).

215. See, e.g., Kansas v. Colorado, 206 U.S. 46, 97 (1907); Iowa v. Illinois, 147 U.S. 1, 8 (1893) (settling interstate boundary disputes by reference to rules of international law).

216. The United Nations General Assembly adopted a definition of aggression in 1974 that is fully susceptible to legal application. See G.A. Res. 3314, 29 U.N. GAOR Supp. (No. 31) at 142, U.N. Doc. A/9631 (1974). In the Nicaragua case, the ICJ rejected the United States' political question arguments. See 
has not been made for excluding transnational public suits from our courts for want of judicial competence.

Apart from the competence of individual courts to hear individual cases, we must ask about systemic competence: whether the influx of transnational public law litigation would overburden the capacity of our entire judicial system. Yet once again, I would argue that no overbroad rule is required to prevent judicial inundation by transnational public cases, so long as courts use existing civil procedure doctrines to eliminate particular unfit cases.

In the three decades since Sabbatino, American courts have developed a body of procedural doctrine that has both complemented and facilitated the emerging phenomenon of transnational litigation: what I call the Federal Rules of Transnational Civil Procedure. ${ }^{217}$ These rules, developed principally in the context of transnational commercial cases, have extended to international settings pre-existing procedural doctrines of subject matter jurisdiction, ${ }^{218}$ personal jurisdiction, ${ }^{219}$ attachment, ${ }^{220}$ service of process, ${ }^{221}$ venue, ${ }^{222}$ choice of law, ${ }^{223}$ discovery, ${ }^{224}$ and the recognition and enforcement of foreign judgments and arbitral awards. ${ }^{225}$ The courts have evolved these rules

generally Norton, The Nicaragua Case: Political Questions Before the International Court of Justice, 27 VA. J. INT'L L. 459 (1987).

217. This body of rules, which has largely been judicially created, deserves much fuller examination than can be given here. What follows is the sketch of a forthcoming article on that subject. The best current compendium regarding the Federal Rules of Transnational Procedure is G. BORN \& D. WESTIN, supra note 212. For valuable introductory discussions of the emerging field of international civil litigation, see id. at 1-18; Burbank, The World in Our Courts, 89 MICH. L. REV. 1456 (1991).

218. See, e.g., United States v. Aluminum Co. of Am., 148 F.2d 416 (2d Cir. 1945); Timberlane Lumber Co. v. Bank of America, 549 F.2d 597 (9th Cir. 1976) (defining scope of subject matter jurisdiction over extraterritorial conduct under antitrust laws).

219. See, e.g., Asahi Metal Indus. Co. v. Superior Court of Cal., 480 U.S. 102 (1987) (denying state court personal jurisdiction over indemnity claim against foreign manufacturer); Helicopteros Nacionales de Colombia, S.A. v. Hall, 466 U.S. 408 (1984) (denying state court general jurisdiction over foreign corporation); Paulson Investment Co. v. Norbay Sec., Inc., 603 F. Supp. 615 (D. Or. 1984) (applying "national contacts" test for personal jurisdiction under securities statute).

220. See, e.g., Reading \& Bates Corp. v. National Iranian Oil Co., 478 F. Supp. 724 (S.D.N.Y. 1979) (prejudgment attachment of Iranian assets during Iran Hostage Crisis).

221. See, e.g., Volkswagenwerk Aktiengesellschaft v. Schlunk, 486 U.S. 694 (1988) (holding Hague Service Convention to be mandatory when service of process must be effected abroad, but finding that internal forum law alone determines when service abroad must be made); Proposed FED. R. CIV. P. 4, reprinted in Preliminary Draft of Proposed Amendments to the Federal Rules of Appellate Procedure and the Federal Rules of Civil Procedure, 127 F.R.D. 237, 266-301 (1989) [hereinafter Preliminary Draft].

222. This doctrine may be subdivided into those cases concerning forum-selection clauses, see, e.g., The Bremen v. Zapata Offshore Co., 407 U.S. 1 (1972) (stating strong presumption favoring enforcement of forum-selection clauses in transnational cases), and those concerning forum non conveniens, see, e.g., Piper Aircraft Co. v. Reyno, 454 U.S. 235 (1982) (stating test for fortum non conveniens dismissal in transnational cases); In re Union Carbide Corp. Gas Plant Disaster at Bhopal, India in December 1984, 634 F. Supp. 842 (S.D.N.Y. 1986), aff'd in part, 809 F.2d 195 (2d Cir. 1987) (applying Piper test to Bhopal case).

223. The Act of State Doctrine is one obvious federal choice-of-law principle. See supra note 106.

224. See, e.g., Societe Nationale Industrielle Aerospatiale v. United States Dist. Court, 482 U.S. 522 (1987) (applying ad hoc comity analysis to interpretation of Hague Evidence Convention); Proposed FED. R. CIV. P. 26, reprinted in Preliminary Draft, supra note 221, at 317-21.

225. Hilton v. Guyot, 159 U.S. 113 (1895) (enforcement of foreign judgments); Mitsubishi Motors Corp. v. Soler Chrysier-Plymouth, Inc., 473 U.S. 614 (1985) (enforcement of foreign arbitration clause); 
on a case-by-case basis, with only occasional Supreme Court direction, ${ }^{226}$ with sporadic reference to treaties and largely outside the context of the formal Federal Rule-making process. Nevertheless, like the formal Federal Rules of Civil Procedure, these transnational rules are "trans-substantive," inasmuch as they can apply equally to cases involving private contracts and public torture. ${ }^{227}$ Like the transnational public law precedents, these procedural cases reflect judicial concerns about comity, but unlike those cases, they also reflect desires to promote uniformity of procedural rules and deference to party autonomy in transnational business decisions. ${ }^{228}$ Because they concern the procedural power of the federal courts to promote national uniformity, they lie squarely within the scope of federal courts' common lawmaking power after Sabbatino. ${ }^{229}$ And some of these rules have acquired such prominence as to provoke (or nearly provoke) changes in the formal Federal Rules. ${ }^{230}$

To invoke these procedural doctrines is not to celebrate all-or even many-of the cases that comprise them. But just as the federal jurisdiction doctrines discussed above were designed to address separation-of-powers concerns, these doctrines of civil procedure have been designed specifically to screen out cases that courts are incompetent to decide. Judiciously applied, the doctrines of personal jurisdiction, exhaustion of local remedies, and forum non conveniens, coupled with practical limits on the availability of service of process, attachable assets, and extraterritorial discovery would screen out untriable transnational public suits before they reached the merits.

Only meritorious cases lacking fatal procedural infirmities, such as Filartiga, would run the gauntlet to judgment. Given that judges regularly apply these procedural principles to ensure the just and speedy decision of transnational commercial cases, why should they abstain from deciding all transnational public cases on political question grounds, citing "judicial incompetence" as the rationale? Pragmatic concerns cannot justify meat-cleaver judicial approaches to transnational public law cases, any more than constitutional concerns can.

Parsons \& Whittemore v. Societe Generale de L'Industrie du Papier (RAKTA), 508 F.2d 969 (2d Cir. 1974) (enforcement of foreign arbitral award).

226. Because of their rarity, Supreme Court rulings in this area, like those in the area of administrative law, tend to have unusually long reverberations. $C f$. Scalia, Vermont Yankee: The APA, the D.C. Circuit. and the Supreme Court, 1978 SUP. CT. REV. 345.

227. Cover, For James Wm. Moore: Some Reflections on a Reading of the Rules, 84 YALE L.J. 718, 718 (1975).

228. See, e.g., The Bremen v. Zapata Offshore Co., 407 U.S. I (1972) (deferring to will of contracting parties in concluding forum-selection clause).

229. See Henkin, supra note 23 , at 1563 n.32 (suggesting that judge-made rules in international relations regarding judicial function may even "be constitutionally immune from congressional regulation").

230. The most recent Proposed Amendments to the Federal Rules of Civil Procedure, drafted by the Federal Rules Advisory Committee, contained modifications to FED. R. CIV. P. 4 and 26 that were influenced by the Schlunk and Aerospatiale cases, respectively. See generally Preliminary Draft, supra note 221. On April 30, 1991, however, (the last day that the rules lay before the Justices), the Court chose not to transmit those modifications to Congress. See 111 S. Ct. ccxiv (1991); Burbank, supra note 217, at 1456 n*. 


\section{Comity Concerns}

Not surprisingly, comity concerns are also best addressed through the same doctrinal-targeting strategy. Upon examination, the Act of State doctrine fits into a much larger jigsaw puzzle that makes up the American "Law of Foreign Sovereignty." That doctrinal map also embraces foreign sovereign immunity, head-of-state immunity, ${ }^{231}$ diplomatic immunity, ${ }^{232}$ the foreign sovereign compulsion defense, ${ }^{233}$ and the extraterritoriality doctrine. ${ }^{234}$ Like the Federal Rules of Transnational Procedure, these doctrines run throughout both transnational private and public law litigation. The doctrines take different legal and procedural forms and attach in different litigation settings. ${ }^{235}$ Nevertheless, all of these doctrines present faces of foreign sovereignty in American courts, and American judges have gained increasing familiarity with their application. Each requires United States courts either to defer to foreign sovereignty when exercising jurisdiction or applying rules of law, or to treat the challenged act of a foreign sovereign or its agent as presumptively or conclusively valid. Moreover, each doctrine reflects not simply comity, but also separationof-powers and judicial competence concerns, by limiting the freedom of the courts to make determinations regarding the legality of acts of foreign sovereigns or officials.

During the last two decades, the most consistent trend across these doctrines has been a discernible decline in the American deference to foreign sovereignty. ${ }^{236}$ This decline has been reflected in the judiciary's expansion of exceptions to the Act of State doctrine, ${ }^{237}$ its liberal reading of the commercial activity exception to the Foreign Sovereign Immunities Act, ${ }^{238}$ its refusals to

231. See, e.g., In re Grand Jury Proceedings Doe No. 700, 817 F.2d 1108 (4th Cir.), cert. denied, 484 U.S. 890 (1987); In re Doe, 860 F.2d 40 (2d Cir. 1988) (Marcos); U.S. v. Noriega, 746 F. Supp. 1506 (S.D. Fla. 1990); Estate of Domingo v. Republic of Philippines, 694 F. Supp. 782 (W.D. Wash. 1988), app. dismissed, 895 F.2d 1416 (9th Cir. 1990).

232. See Diplomatic Relations Act, Pub. L. No. 95-393, 92 Stat. 808 (1978) (codified at 22 U.S.C. $\S 254 a-e(1988)$ ) (implementing 1961 Vienna Convention on Diplomatic Relations).

233. See, e.g., O.N.E. Shipping Ltd. v. Flota Mercante Grancolombiana, S.A., 830 F. 2d 449, 453 (2d Cir. 1987) (alternative ground of dismissal), cert. denied, 488 U.S. 923 (1989); Interamerican Refining Corp. v. Texaco Maracaibo, Inc., 307 F. Supp. 1291 (D. Del. 1970); Note, The Uncertain Status of the Defense of Foreign Sovereign Compulsion: Two Proposals for Change, 31 VA. J. INT'L L. 321 (1991).

234. See, e.g., EEOC v. Arabian American Oil Co., 111 S. Ct. 1227 (1991) (declining to apply Title VII extraterritorially to U.S. citizen employed abroad by U.S. employer).

235. For example, principles of diplomatic and foreign sovereign immunity are embodied in statutes; the foreign sovereign compulsion defense and Act of State doctrine are federal common law rules; and the extraterritoriality doctrines are often stated in the form of canons of statutory construction. Foreign sovereign immunity is a jurisdictional limit on the federal courts; the individual immunities are usually stated as affirmative defenses; and the Act of State, foreign sovereign compulsion, and extraterritoriality doctrines are considered rules of decision. Some of these doctrines, e.g., foreign sovereign immunity, attach only to foreign sovereign defendants in civil cases, while diplomatic and head-of-state immunity attach in both civil and criminal proceedings (subject to certain exceptions in civil cases).

236. The forthcoming article described in supra note 217 will trace these trends in greater detail.

237. See supra note 108 .

238. See, e.g., Texas Trading \& Milling Corp. v. Federal Republic of Nigeria, 647 F.2d 300 (2d Cir. 1981), cert. denied, 454 U.S. 1148 (1982). 
immunize ex-heáds of state ${ }^{239}$ or to entrench the foreign sovereign compulsion defense, ${ }^{240}$ Congress' proposals to limit diplomatic immunity, ${ }^{241}$ and the Executive's willingness to assert American law extraterritorially. ${ }^{242}$ Paradoxically, this general decline in deference in transnational cases has accompanied greater judicial willingness simultaneously to invoke the amorphous concept of comity. ${ }^{243}$

Not all of these trends have been well-conceived. Some judicial decisions have confused respect for foreign sovereignty with immunization of responsible officials. ${ }^{244}$ Others have been strikingly insensitive to protection of individual rights, which as Professor Brilmayer correctly argues, forms a core part of the judicial role. ${ }^{245}$ Although these doctrines hardly form a seamless web, they do empower courts to give foreign sovereignty its due in particular transnational public law cases. Thus, in Amerada Hess, the Court required plaintiffs to proceed against Argentina under the Foreign Sovereign Immunities Act. ${ }^{246}$ In Saltany v. Reagan, the D.C. Circuit invoked head-of-state immunity, at the executive branch's request, to immunize Margaret Thatcher from liability for her role in the United States' bombing of Libya. ${ }^{247}$ At the same time, the courts have carefully withheld the cloak of foreign sovereignty from former dictators, particularly when they have been sued by successor governments who have waived their past immunities. ${ }^{248}$

Once again, doctrinal targeting will address valid comity concerns far better than blanket deference to foreign sovereignty. Unlike Brilmayer's simpler proposal, which can be easily manipulated, the very range and specificity of these doctrines provide "disciplining rules" that constrain judges to engage in forthright decisionmaking. ${ }^{249}$ Of course, judges must beware certain traps even

239. See cases cited in supra note 231.

240. The Supreme Court avoided endorsement of the foreign sovereign compulsion defense in Matsushita Elec. Indus. Co. v. Zenith Radio Corp., 475 U.S. 574, 598 (1986). See generally Note, supra note 233, at 329-39 (tracing judicial evolution of defense).

241. See, e.g., S. 2771, 98th Cong., 2d Sess. (1984) (making use of firearm by diplomat to commit felony a federal crime).

242. See, e.g., Compagnie Europeenne des Petroles S.A. v. Sensor Nederland B.V., District Court at the Hague, Netherlands (1982), reprinted in 22 I.L.M. 66 (1982) (finding American extraterritorial extension of Soviet pipeline sanctions to violate international law); see generally Extraterritoriality of Economic Legislation, 50 LAW \& CONTEMP. PROBS. 11 (1987).

243. See, e.g., Societe Nationale Industrielle Aerospatiale v. United States Dist. Court, 482 U.S. 522 (1987); see generally Paul, supra note 59.

244. See, e.g., Chuidian v. Philippine Nat'l Bank, 912 F.2d 1095 (9th Cir. 1990) (reaching anomalous conclusion, over objection of U.S. government, that FSIA applies to individuals).

245. See, e.g., EEOC v. Arabian American Oil Co., 111 S. Ct. 1227 (1991) (refusing to apply Title VII extraterritorially to U.S. citizen employed by U.S. company overseas); United States v. VerdugoUrquidez, 110 S. Ct. 1056 (1990) (refusing to apply warrant clause of Fourth Amendment extraterritorially to search of alien's property even though alien was being held for trial in U.S. while search occurred).

246. See text accompanying supra notes 132-33.

247. See supra note 135 .

248. See cases cited supra note 231.

249. Cf. Fiss, Objectivity and Interpretation, 34 STAN. L. REV. 739, 744 (1982) ("disciplining rules ... constrain the interpreter and constitute the standards by which the correctness of the interpretation is to be judged"). 
under a doctrinal-targeting approach. They ought not, for example, defer to an executive suggestion that an institutional reform case be dismissed (to avoid unconstitutional interference with foreign policy), then go on, for good measure, to hold the case unmanageable on incompetence grounds and to immunize the foreign defendant on comity grounds. These superfluous alternative holdings will spawn precedent just as surely as the dispositive ones and may insulate the key issue from appellate review. Similarly, judges should avoid doctrinal mismatches, i.e., dismissing a case on judicial competence grounds that actually reflects comity and separation-of-powers concerns. ${ }^{250}$ But once again, the very specificity of the doctrinal rulings to be made increases the transparency of lower court rulings to appellate review. If, as in the case of foreign sovereign immunity, this body of law becomes too confusing and complex for the courts, it may ultimately be codified and rationalized by Congress. But in exercising their reviewing function both Congress and appellate judges should recall Nuremburg and be skeptical of overblown claims of foreign sovereignty. After all, they should ask. if courts can now adjudicate foreign sovereign responsibility for breach of garden-variety contracts, why not torture?

\section{DOMESTIC COURTS AND \\ THE NEW INTERNATIONAL LEGAL PROCESS}

\section{A. Marbury's Legacy}

In the end, Brilmayer hesitates about transnational public law litigation because its model of judicial decisionmaking is too "politically ambitious." She argues that transnational public law litigants should learn from the travails of Chayes' domestic public law litigation. ${ }^{251}$ If one aspires to a more ambitious role for international litigation in United States courts, she warns, one risks being stranded on the advancing shoals of judicial restraint. To highlight the comparative modesty of her geometric model, she names it after Marbury. "Declaration of international legal principles," she says, "is not an end in itself, but an indispensable part of the performance of a traditional duty" to protect individuals. 252

Having already explained why Brilmayer's model is misguided, let me suggest why it is also misnamed. As I have already illustrated, her proposal can be manipulated in a way that makes it far more revolutionary than modest. Nor

250. See, e.g., Islamic Republic of Iran v. Pahlavi, 94 A.D.2d 374, 464 N.Y.S.2d 487 (N.Y. App. Div. 1983), aff'd on other grounds, 62 N.Y.2d 474, 467 N.E.2d 245, 478 N.Y.S.2d 597 (N.Y. 1984), cert. denied, 469 U.S. 1108 (1985) (dismissing case on forum non conveniens grounds although no alternative forum existed to entertain suit).

251. Brilmayer, supra note 12, at 2313. But see Marcus, Public Law Litigation and Legal Scholarship, 21 U. MICH. J.L. REF. 647, 648 (1988) (suggesting that judges' experience with kinds of cases Chayes was describing has had salutary effect on their decisionmaking).

252. Brilmayer, supra note 12 , at 2312 . 
is her vertical model of international adjudication faithful to anything but the most anachronistic reading of Marbury. As commentators have now recognized, Marbury itself intertwined a traditional view of litigation as dispute-resolution with the more modern view of litigation as public action. ${ }^{253}$ To be sure, Marbury recognized that courts play a special structural role in protecting individuals against government. But it equally addressed the rights and responsibilities of federal judges as guardians and expositors of federal law. In the transnational setting, Marshall's vision of the role of American courts translates directly into the declarative role they now play in transnational public law litigation model. ${ }^{254}$

Brilmayer's view would be better dubbed the "Choper Model." For like Jesse Choper, who argues that courts should husband their resources in constitutional cases for protection of individual rights, Brilmayer suggests that courts should similarly husband their resources in international cases. ${ }^{255}$ Policing the structures of government, both suggest, is something that the political branches should do without judicial help. But, in my view, both endorse a narrow and unrealistic understanding of the judicial role.

The transnational public law litigation model is both descriptively and prescriptively superior to the "traditional" alternative. It is descriptively superior because there are important differences between what American judges say and what they do when they decide international law cases. Although they claim to be resolving disputes in one case only, they are actually declaring (or not declaring) international norms that litigants transport to other fora for use in political bargaining. Although they may claim to be deciding cases by traditional procedures, judges are in fact applying Federal Rules of Transnational Procedure in these cases, no less than they apply the Manual of Complex Litigation in domestic institutional reform cases. By weaving the doctrinal tapestry that creates, for example, the American Law of Foreign Sovereignty, they determine the jurisdictional boundaries and conflicts that help shape geopolitical and economic relationships among America and its global partners. Although judges seek to avoid playing roles in international politics, they inevitably do so both by deciding cases and by not deciding them. Although they may claim to be avoiding politics by not deciding cases under international law, such "non-decisions" frequently ally them with the forces of violence. ${ }^{256}$ In short, just as

2S3. See, e.g., Amar, supra note 181, at 702 n.69. 713 n.138; $i d$. at 712 (Marbury was "itself a suit seeking affirmative relief against a federal official despite the absence of an obvious violation of common law rights.").

254. This should not be surprising given Marshall's own rulings regarding international law. See cases cited supra notes $51-53$.

255. Cf. J. Choper, Judicial Review and the National political Process 2 (1980). Indeed, Brilmayer cites Choper's book to support her model. See Brilmayer, stipra note 12, at $2321 \mathrm{n}$.133. For persuasive critiques of Choper's view, see Monaghan, Book Review, 94 HARV. L. REV. 296 (1980); Tribe, On Reading the Constitution, 1988 UTAH L. REV. 747, 768-69.

256. See Cover, supra note 96 , at 57. 
Choper cannot seriously suggest that cases like Marbury and INS $v$. Chadha ${ }^{257}$ merely policed governmental structure and did not affect individuals, judges simply delude themselves if they believe that avoiding horizontal, "political" decisions in international cases will have no impact upon rights.

Transnational public law litigation better describes not just what judges are doing, but also what litigants are doing. By filing the Bhopal case in American court, India was no more seeking a traditional tort judgment than Linda Brown was seeking just to walk fewer blocks to a school bus in Topeka, Kansas. Both were seeking judicial declarations of systemic wrongfulness, declarations that they could then use to convert principle into political power. At a minimum, then, transnational public law litigation is the superior lens because it is the more candid. Rather than pretending that litigants merely seek dispute-resolution and that judges merely weigh horizontal and vertical elements, transnational public law litigation openly confronts what both are doing and why they are doing so.

But why is transnational public law litigation a normatively superior model of judicial decisionmaking? This question can, of course, be rephrased in terms of judicial competence, separation of powers, and comity. Why shouldn't American courts stick to deciding domestic cases and controversies, staying out of foreign policy, and avoiding judgment on the conduct of foreign sovereigns? The answer: they have traditionally done more; they are institutionally capable of doing more; and their traditional performance demonstrates that they are not only constitutionally authorized, but uniquely positioned, to play a more constructive role in the international legal process.

As Part I demonstrated, our constitutional and historical traditions not only charge the courts with chief responsibility for preventing abuse of state power against individuals, but also with giving domestic meaning to the shared public values expressed by treaties and customary international law. Justice White put it well in his Sabbatino dissent:

Principles of international law have been applied in our courts to resolve controversies not merely because they provide a convenient rule for decision but because they represent a consensus among civilized nations on the proper ordering of relations between nations and the citizens thereof. Fundamental fairness to litigants as well as the interest in stability of relationships and preservation of reasonable expectations call for their application whenever international law is controlling in a case or controversy. 258

257. 462 U.S. 919 (1983) (striking down legislative veto and sparing alien from deportation). Marbury, of course, defined the structural role of the courts in a system of separation of powers, even as it addressed the question of Marbury's individual right to his judicial commission.

258. Banco Nacional de Cuba v. Sabbatino, 376 U.S. 398,453 (1964) (White, J., dissenting). 
As I have argued above, American courts have fully demonstrated their institutional capacity to decide transnational public law cases. If they use the doctrinal-targeting strategy I favor, courts can adjudicate international law cases without arousing the policy concerns that have influenced the gradual contraction of their role.

Are such adjudications constitutionally authorized? As Professor Fiss has argued, the executive branch and Congress are not the only law-pronouncing entities within our governmental structure; courts represent a coordinate source of governmental power with independent common lawmaking capacity. ${ }^{259}$ As Sabbatino acknowledged, this is particularly true with regard to international relations, where the authority of the several states is weakest and the need for national uniformity is the greatest. ${ }^{260}$ Through our constitutional structure, the people have given their consent to this arrangement. As Marbury recognized, within this structure, it is the province and duty of the federal courts to say what the law is. Moreover, courts are unusually well-positioned to enunciate norms, because of both their independence and their willingness to engage in dialogue over legal meaning. ${ }^{261}$

In international cases that dialogue proceeds not just between courts and litigants, or between courts and the political branches, but also between American courts and other law-declaring institutions of the international system. As we have seen, decisions like Nuremburg, Filartiga, and the PLO Mission case are, in Cover's term, "jurisgenerative," because they both create law and initiate a dialogue with foreign and international courts that engenders further normdeclaration. ${ }^{262}$ Those norms may take the form of federal common law, canons of domestic statutory construction, foreign or international court decisions, customary international law rules, or human rights treaties. In short, by encouraging dialogue between domestic and international law-declaring institutions, transnational public law litigation moves us closer to a unitary, "monist" legal system, in which domestic and international law are integrated. ${ }^{263}$ Far from being radical, such decisions follow our nation's traditional, historic judicial practice.

Even serving as only an interstitial source of legal norms, transnational public law litigation nevertheless serves salutary social purposes. If, as in the case of international tort suits like Filartiga, courts award judgments, the lawsuit promotes the classic tort goals of compensation, deterrence and punish-

259. See Fiss, supra note 7, at 125 ("The people's consent is required to legitimate the political system, of which the judiciary is an integral part, and the capacity of the people to respond to judicial decisions, say, through constitutional amendments, preserves the consensual character of the system as a whole. A tighter, more particularized dependence on the popular consent will deprive the judiciary of its independence and thus its competence to speak the law."); see also Fiss, supra note 98.

260. See supra text accompanying note 199.

261. See Fiss, supra note 7 , at 125.

262. Cover, supra note 96 , at 57-58 ("When [judges] oppose the violence and coercion of other organs of the state, judges begin to look more like the other jurisgenerative communities of the world.").

263. See supra note 10. 
ment. Even if the judgment is never collected, the judicial goal of protecting individuals is served and repose and safe haven are effectively denied to perpetrators of international crimes. ${ }^{264}$ If, as is often the case with stateinitiated suits, the norm generated by the lawsuit mainly spurs a political bargain, the suit nonetheless promotes useful dispute-resolution ends. And if, as in institutional-reform suits, the lawsuit encourages national decisionmakers to pay greater heed to treaties or customary norms, the litigation has, in effect, set standards of lawfulness for the conduct of responsible officials. In short, even functioning largely as an adjunct to the traditional model of disputeresolution, the model of transnational public law litigation can play an enormously useful role in providing relief for individuals, even as it spurs the recognition of developing global norms.

Although Professor Brilmayer recalls Marbury as the paradigm of judicial modesty, each of these aspirations was equally present there: the search for individual redress through innovative remedies, the judicial examination of official conduct, and ultimately the powerful declaration of an organic role for judges in declaring norms. ${ }^{265}$ Thus, far from breaking Marbury's mold, transnational public law litigation fits comfortably within its broader tradition.

\section{B. The New International Legal Process}

In closing, it is worth asking what relevance, if any, transnational public law litigation has to the newly emerging possibilities for international law. Despite our President's rhetoric after the Iraq war, claims of a "New World Order" remain overblown. Certainly, we will not recapture the postwar San Francisco ideal: the positivists' dream of a world order under world law, guided by international institutions and constitutions. But neither will we soon return to the "revolutionary" Cold War balance-of-power system that so often rendered international law and institutions impotent. ${ }^{266}$ During the Cold War, international legal scholars generated three main responses to the cynicism of both legal realism and political realism: an "idealist" strand, which held unrealistically high aspirations for world institutions and constitutions;, 267 a "policy-oriented approach" that sought a "world public order of human dignity"; 268 and an

264. See supra note 11.

265. See generally Amar, Marbury, Section 13, and the Original Jurisdiction of the Supreme Court, 56 U. CHI. L. REV. 443 (1989).

266. Hoffmann, International Organization and the International System, in JANUS AND MINERVA: ESSAYS IN THE THEORY AND PRACTICE OF INTERNATIONAL POLITICS 293, 294 (1987) (contrasting "revolutionary" and "moderate" international systems) ("A revolutionary system wracked by inexpiable power rivalries and ideological conflicts is one in which international organization is reduced to impotence as a force of its own ....").

267. See, e.g., G. Clark \& L. SOHN, INTROdUCtION TO WORLd PEACE Through WORLD LAW (rev. ed. 1984).

268. See, e.g., INTERNATIONAL LAW ESSAYS: A SUPPLEMENT TO INTERNATIONAL LAW IN WORLD PUBLIC PERSPECTIVE (M. McDougal \& W. Reisman eds. 1981). 
"International Legal Process" school, which like its domestic counterpart, studied process and urged national decisionmakers to engage in reasoned elaboration. ${ }^{269}$

All three schools lost vibrancy over time. As Professor Trimble has noted, "the institution-building idealist writers were vulnerable to broad attacks on the discipline by [political] realists like Kennan, Acheson, and Morgenthau."270 The interdisciplinary policy scientists, in Stanley Hoffmann's words, began to "analyze law in policy terms which miss[ed] the distinctiveness of law as a method of social control ... [,] ironing out the normative essence of law under the pretext of straightening the discipline."271 The International Legal Process scholars declined into "thick description," increasingly exalting process over value, law over politics, and the how over the why. Simultaneously, their domestic Legal Process mentors went much the same route, taking a restrained view of the judicial function that urged courts to apply the passive virtues, leaving political decisions to the more representative branches. ${ }^{272}$

Contemporary domestic scholars reacted against the Legal Process movement in now-familiar ways, including the "law and" movement, the critical legal studies and critical race studies movements, feminism, and the "new legal process" school, which has emphasized interpretation and dialogue as forces that justify a less constricted judicial role in American political life. ${ }^{273}$ Yet by comparison, contemporary international legal scholars have done almost nothing to respond to the far greater intellectual poverty of their field, instead focusing upon synthesis and refinement of existing theses ${ }^{274}$ or rejecting them from the left in the language of the right. ${ }^{275}$

Amidst the rhetoric of a "New World Order," we should ask whether we can shake the idealist/realist polarities that dominated Cold War debate in order to develop a new model of the international legal process that captures its

269. See A. CHAYES, T. EHRLICH \& A. LOWENFELD, INTERNATIONAL LEgal PROCESS: MATERIALS FOR AN INTRODUCTORY COURSE (1968) (two-volume set). That work explicitly derived from Henry Hart's and Albert Sacks' famous unpublished casebook. See id. at xxi (referring to H. Hart \& A. Sacks, The Legal Process: Basic Problems in the Making and Application of Law (1958) (unpublished manuscript)).

270. Trimble, International Law, World Order, and Critical Legal Studies, 42 STAN. L. REV. 811,822 (1990).

271. Hoffmann, The Study of International Law and the Theory of International Relations, 57 AM. SOC'Y INT'L PROC. 26, 27 (1963).

272. See Eskridge, Metaprocedure (book review), 98 YALE L.J. 945, 963-66 (1989); Weisberg, The Calabresian Judicial Artist: Statutes and the New Legal Process, 35 STAN. L. REV. 213, 217 (1983).

273. See Weisberg, supra note 272, at 239-49; see also Eskridge \& Peller, The New Public Law Movement: Moderation as a Postmodern Cultural Form, 89 MiCH. L. REv. 707, 709-37 (1991) (tracing the evolution of the new legal process and the "new public law").

274. See, e.g., L. CHEN, AN INTRODUCTION TO CONTEMPORARY INTERNATIONAL LAW (1989) (summarizing approach of New Haven School).

275. Critical legal scholars in international law have argued that international law is indeterminate and incoherent, but have not committed themselves "to an affirmative image of the role of international law in the world order." Purvis, Critical Legal Studies in Public International Law, 32 HARV. INT'L L.J. 81, 116 (1991). As a result, some of their critiques read like the work of political realists, who were skeptical, to say the least, about the possibilities of international law. See, e.g., Kennedy, The New Stream of International Legal Scholarship, 7 WIS. INT'L L.J. 1 (1991). 
complex richness: its intricate mix of positivist, customary, and declarative law:276 its allocation of functions among a diverse blend of international institutions and regimes, regional and bipolar compacts, and national governmental actors; ${ }^{277}$ and its emerging modes of executive action, administration, legislation, and dispute-resolution. ${ }^{278}$ Such an inquiry would borrow from many forbears. Like the idealists, we must focus on positivist constructs, but our gaze must also extend to informal regimes and decisionmaking processes, informal norms, and customary, declarative, and einerging "soft" rules of international law. Like the policy scientists, we must incorporate the insights of other disciplines without losing sight of the uniquely normative function of law to shape international action and of international regimes to shape law. ${ }^{279}$ Like traditional legal process scholars, we must focus on process and legal doctrine, but we should press further to examine underlying values and the shaping power of doctrine on politics and institutional incentives.

My appraisal of transnational public law litigation has partly attempted to answer this plea, for it has examined how domestic courts and transnational litigants do, and should, participate in this "new" international legal process. ${ }^{280}$ Although Professor Brilmayer warns against the possible "ebb tide" of transnational public law litigation, ${ }^{281}$ she confines her gaze too narrowly to the domestic arena. A broader look at the shape of international legal process reveals that we stand at a moment of startling, perhaps unprecedented, revival in transnational adjudication. As Part $l$ described, the Cold War triggered a steady decline of traditional international adjudication, which reached its nadir in 1985 when the United States (previously, the most ardent advocate of international adjudication) terminated its acceptance of the compulsory jurisdiction of the World Court. ${ }^{282}$ But as the political institution of international

276. See Chodosh, supra note 107.

277. See H. KOH, supra note 1 , at 120 (describing this phenomenon).

278. New forms of executive action have taken place, for example, through the informal decisionmaking procedures of the Group of Seven Nations. See, e.g., R. PUTNAM \& N. BAYNE, HANGING TOGETHER: COOPERATION AND CONFLICT AT THE SEVEN-POWER SUMMITS (rev. ed. 1987) (describing that process). Administrative decisionmaking and enforcement have been done, for example, by the highly informal COCOM process and the somewhat more formal United Nations peacekeeping regime. See, e.g., Aeppel, The Evolution of Multilateral Export Controls: A Critical Sudy of the CoCom Regime, 9 FLETCHER FORUM 105 (1985); Siekmann, The Codification of Generzl Principles for United Legal Aspects of UN Peacekeeping Operations, 1988 NETH. INT'L L. REV. 328. New forms of quasi-legislation include the international "soft" law found particularly in the international environmental area and what Chodosh calls "declarative international law." See Chodosh, supra note 107; A Hard Look at Sofi Law, 82 AM. SOC'Y INT'L Proc. 371 (1988). Transnational public law litigation is itself one of the new forms of dispute-resolution referred to in text.

279. For recent efforts to combine international legal analysis with regime theory, see Abbott, Modern International Relations Theory: A Prospectus for International Lawyers, 14 YALE J. INT'L L. 335 (1989); Abbott, The Trading Nation's Dilemma, 26 HARV. INT'L L.J 501 (1985).

280. For an earlier effort at "new legal process" analysis in the international relations area, focusing on the Constitution and foreign affairs, see $\mathrm{H}$. $\mathrm{KOH}$, supra note 1, at 224-28.

281. Brilmayer, supra note 12, at 2312.

282. See Letter from Secretary of State George P. Shultz to Secretary-General of the United Nations Javier Perez de Cuellar (Oct. 7, 1985), reprinted in 24 I.L.M. 1742 (1985) (terminating U.S. acceptance of compulsory jurisdiction of International Court of Justice). 
adjudication failed, the legal regime of transnational adjudication adapted, and steadily shifted into fora other than plenary review in contentious cases before the ICJ. At the global level, we witnessed the birth of transnational tribunals for the resolution of expropriation disputes and the burgeoning of a quasiarbitral process before the ICJ itself. ${ }^{283}$ At the regional level, we witnessed the rise of regional courts, ${ }^{284}$ particularly in the human rights area, and at the bilateral level, new and innovative standing arbitral tribunals to decide large dockets of controversial cases. ${ }^{285}$ Finally, as we have seen, transnational private and then public litigation began haltingly to emerge in American federal courts.

These proxies for traditional international adjudication all developed in part to compensate for the general decline of both the General Agreement on Tariffs and Trade (GATT) and the ICJ as international judicial fora. Yet the Cold War's startling end sparked myriad new possibilities for multilateral cooperation under international law. In 1987, Mikhail Gorbachev embraced both the United Nations and international law with an ardor evoking Eleanor Roosevelt more than Nikita Khruschev, and triggered a remarkable chain of Soviet initiatives toward the international system. ${ }^{286}$ Perhaps the most vivid illustration of the revival came at the International Court of Justice itself. In 1979, when the United States sued Iran at the World Court over the seizure of the Tehran hostages, Iran refused to appear. Five years later, when Nicaragua sued the United States there for covert paramilitary activities, the United States withdrew. But when Iran sued the United States at the World Court in 1989 over the downing of an Iranian Airbus by the U.S.S. Vincennes, both countries appeared! $!^{287}$ At this writing, the ICJ has more cases on its docket than ever

283. See, e.g., the World Bank arbitration process under its Convention on the Settlement of Investment Disputes, and the World Court's increased use of the ad hoc Chamber procedure; see Meyer, The Ad hoc Chambers: Perspectives of the Parties and the Court, 27 ARCHIV DES VOLKERRECHTS 413 (1989).

284. See, e.g., the European and Inter-American Courts of Human Rights and the creation of a court of first instance in the European Court of Justice in the Single European Act. See generally Slynn, Court of First Instance of the European Communities, 9 NW. J. INT'L L. \& BUS. 542 (1989).

285. See, e.g., the Iran-U.S. Claims Tribunal, the Article 18 and 19 binational review panels under the U.S.-Canada Free Trade Agreement. See generally Note, The Binational Panel Mechanism for Reviewing United States-Canadian and Countervailing Duty Determinations: A Constitutional Dilemma?, 29 VA. J. INT'L L. 681 (1989), and the similar dispute-resolution processes being proposed under the forthcoming North American Free Trade Agreement.

286. In his extraordinary speech, entitled "The Reality and Guarantees of a Secure World," Gorbachev declared his conviction "that a comprehensive system of security is at the same time a system of universal law and order ensuring the primacy of international law in politics." Gorbachev, The Reality and Guarantees of a Secure World, Pravda, Sept. 17, 1987, reprinted in U.S.S.R. Mission to the United Nations, Press Release No. 119, at 11 (Sept. 17, 1987). In short order, the Soviet Union confessed to unlawful aggression in Afghanistan and long-standing violations of the 1972 ABM Treaty, accepted the compulsory jurisdiction of the International Court of Justice without reservation with respect to six international human rights conventions, repaid its U.N. budget arrears, joined the U.S. in brokering ends to the Iran-Iraq War and South African occupation of Namibia, and accepted observer status at the GATT. See generally Franck, Soviet Initiatives: U.S. Responses-New Opportumities for Reviving the United Nations System, 83 AM J. INT'L L. 531 (1989).

287. The facts of that case, Aerial Incident of 3 July 1988 (Iran v. U.S.) (Jurisdiction), are described in Agora: The Downing of Iran Air Flight 655, 83 AM. J. INT'L L. 318 (1989). 
before in its history, and a similar pattern has emerged in the context of GATT Dispute Settlement. ${ }^{288}$

Just as transnational public law litigation in United States courts may ebb or grow, depending in part upon the changing predilections of the federal judiciary, this revival of international adjudication may also flourish, slow, or halt as national geopolitical incentives change, the Gulf War coalition and the Soviet Union dissolve, and new international judgments are obeyed or defied. But clearly, transnational public law litigation itself-a judicial phenomenon with venerable roots-is entering a new era, in which the possibilities for dialogue among American and international tribunals are greater than at any time in modern memory. In this uncertain future, the normative possibilities for transnational public law litigation can only expand. As the future unfolds, the doctrinal debate in which Professor Brilmayer and I have engaged can only assume greater significance for this new international legal process.

288. See Newsletter of the American Society of International Law I (June-July-August 1991) (eleven cases currently pending before the World Court is the largest number at one time since 1946). The United States recently agreed to comply with a GATT panel's finding that Section 337 of the Tariff Act of 1930 violated the GATT, in no small measure because the United States now sees itself as using the GATT panel process as a plaintiff, rather than as a defendant. See generally $A$ Level Playing Field for Global Problems: Section 337-A Case Siudy, PROC. OF EIGHTH ANNUAL JUd. CONF. OF THE U.S. CT. OF APPEALS FOR THE FED. CIRCUIT, 133 F.R.D. 257 (1990) (panel discussion). 